\title{
TRADISI MAHAR DI RANAH LOKALITAS UMAT ISLAM: MAHAR DAN STRUKTUR SOSIAL DI MASYARAKAT MUSLIM INDONESIA
}

\author{
Noryamin Aini \\ Fakultas Syariah dan Hukum UIN Syarif Hidayatullah Jakarta \\ Jl. Ir. H. Juanda No.95, Ciputat, Jakarta Selatan \\ E-mail: noryaminaini@yahoo.com
}

\begin{abstract}
Mahar Tradition in Muslim Locality: Mahar and Social Structure in Indonesian Muslim Society. Law consists of two fundamentals: moral and formal dimensions. Muslim legal scholars greatly appreciate the interplay of both aspects. Legal positivism separates them and law is ultimately framed in a formal-standard logical construct. Legal moral values are universal. It is flexible, universal and can be easily adapted into local contexts. Sociologically, social and cultural structure has proven to play an important role in the structuring of legal format. This paper proves that the practice of dower in a number of Muslim societies changes and varies crossing local boundaries. The dower tradition has been changed from money and other practical objects, into more symbolic materials, namely accessories and religious symbols.
\end{abstract}

Keywords: law, dower, dowry, social structure, social status.

\begin{abstract}
Abstrak. Tradisi Mahar di Ranah Lokalitas Umat Islam: Mahar dan Struktur Sosial di Masyarakat Muslim Indonesia. Hukum memiliki dua unsur utama, moral dan formal. Para fukaha sangat mengapresiasi keduanya. Namun tradisi positivisme hukum mereduksi basis moral. Hukum akhirnya terjebak dalam konstruk logis yang formal-baku. Nilai-nilai moral hukum tetap bersifat universal. Ia seperti benda cair, lentur dan mudah beradaptasi dengan konteks temporer-lokal. Secara sosiologis, struktur sosial dan budaya terbukti berperan penting dalam menstrukturisasi format hukum. Walau secara formal format hukum tetap, faktanya studi ini membuktikan bahwa praktek hukum mahar di sejumlah masyarakat Islam mengalami perubahan dan perbedaan yang signifikan lintas ruang dan waktu. Wujud mahar berubah dari tradisi uang ke format simbol penampilan (perhiasan) dan simbol agama.
\end{abstract}

Kata Kunci : hukum, mahar, maskawin, struktur sosial, status sosial

\section{Pendahuluan}

Analisis sosial menempatkan hukum sebagai fakta sosial. Dalam perspektif ini, hukum lahir dan mengalami pelembagaan dalam bingkai sosial. Intinya, secara sosiologis, hukum adalah efek turunan dari struktur dan dinamika sosial-budaya. Bahkan hukum adalah produk negosiasi politis. Diskursus sosio-legal ini juga berlaku untuk hukum Islam. Pakar hukum Islam sangat menyadari eksistensi inter-relasi, minimal intersepsi hukum dengan struktur sosial. Seorang pakar fikih era skolastik, Ibn Qayyim al-Jawziyyah (w. 751 H/1350 M), menegaskan bahwa hukum Islam seharusnya sebagai refleksi responsif fukaha dalam menyikapi persoalan zaman dengan semangat kedisinian dan kekinian.

Konstruksi hukum Islam, dalam hal ini fikih, kental dengan semangat ruang dan waktu. Kaidah-kaidah fikih

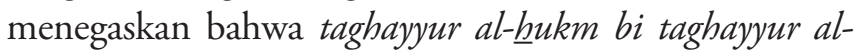

Naskah diterima: 5 Agustus 2013, direvisi: 1 Oktober 2013, disetujui untuk terbit: 20 November 2013. azminah wa al-amkinah (hukum berubah seiring dengan perubahan waktu dan ruang) dan al- $\underline{h u k m}$ yadîr máa 'illatih wujûdan wa 'adaman (eksistensi hukum berevolusi sesuai dengan pergeseran reasoning-nya). Kedua kaidah di atas menegaskan bahwa ketentuan hukum Islam bukan suatu ketetapan azali. Oleh sebab itu keragaman hukum sesungguhnya merupakan fenomena keniscayaan sosial dan budaya. Kearifan apresiasi konteks lokal dan temporal ini nampak jelas dari profil ramah dan bijak Imâm Mâlik (w.179 H/796 M) saat menyikapi permintaan alManshûr (158 H/775 M), penguasa Abbasiyyah untuk mempositivisasi wacana fikih Mâlikî yang terkodifikasi dalam al-Muwaththa'. Imâm Mâlik dengan tegas menolak usulan tersebut dengan alasan bahwa di wilayah-wilayah Islam telah tumbuh dan mengakar mapan praktek fikihfikih lokal lain. ${ }^{1}$ Bagi beliau formalisasi norma fikih adalah

${ }^{1}$ Ahmad ibn 'Abd al-Rahím al-Fârûqî al-Dahlawî (Syâh Wali Allâh), al-Inshâf fì Bayân Sabab al-Ikhtilâf fî al-Ahkâm al-Fiqhiyyah, (Kairo: al-Mathba'ah al-Salafiyyah, 1385 H), h. 12; Jalâl al-Dîn 'Abd alRahmân ibn Abí Bakr al-Suyûthî, Ikhtilâf al-Madzâhib, 'Abd al-Qayyûm 
satu bentuk reduksi terhadap watak elastisitas fikih. ${ }^{2}$

Mahar adalah syarat pernikahan. Dalam sejarah hukum Islam, jenis dan jumlah mahar tidak pernah dibakukan. Mahar terus berubah dan terpolakan secara sosial-kultural-ekonomi. Di era pemerintahan 'Umar ibn al-Khaththâb (w. 23 H/644 M) misalnya, muncul tradisi mahar baru yang super tinggi, nyaris tidak terjangkau standar kemampuan umum. Kaum laki-laki saat itu mengeluhkan besaran mahar. Secara kolektif, keluhan ini disampaikan kepada 'Umar. Beliau lalu berceramah lantang di sebuah mesjid memperingatkan perempuan atas kelakuannya yang memasang standar mahar yang tinggi. Tiba-tiba di satu sudut majelis, seorang perempuan bangkit dan memecah keheningan. Dia dengan vulgar menyela ceramah Umar. Dengan nada kesal, perempuan itu bertutur keras: "Hai Amîr alMukminîn! Apakah baginda akan merampas segala hak istimewa yang telah Allah berikan kepada kami?”. Perempuan tersebut lalu mengutip Q.s. al-Nisâ [4]: 20. Setelah mendengar kritikan tersebut 'Umar lalu mengakui kekhilafan dan meralat segala peringatan dan himbauannya.

Secara historis, mahar berfungsi sebagai satu instrumen legal sentral dalam konsep dan praktek pernikahan Islam. Sejak awal sejarah Islam, praktek mahar mendapat banyak sorotan baik dari sisi keberpihakannya kepada perempuan, signifikansi ideologis, ekonomis atau makna moralnya. Praktek hukum mahar dalam kehidupan umat Islam sangat erat kaitannya dengan dinamika dan struktur sosial. Sejarah konstruksi dan aplikasi mahar adalah potret dinamis interaksi anasir sosial, politik, ekonomi dan budaya, bukan fakta kejumudan. Namun selama ini kajian yang ada tentang mahar masih terlalu terfokus pada dimensi normatifnya. Sementara

Muhammad Syâfi' al-Basthawî, ed. (Kairo: Dâr al-I'tishâm, 1987), h. 2223; al-Qaththân, al-Tasyrî‘ wa al-Figh fì al-Islâm: Târîkhan wa Manhajan, (Bayrût: Muassasah al-Risâlah, 1982), h. 289; Dutton, Asal Mula Hukum Islam: Alqur'an, Muwațta', dan Praktik Madinah, diterjemahkan oleh M.Maufur, (Jogjakarta: Islamika, 2003), h. 56. Ada pendapat yang mengatakan bahwa khalifah yang meminta adalah Hârûn al-Rasyîd (w. 193 H/809 M).

${ }^{2}$ Terkait dengan hal ini pendapat Ibn Qayyim al-Jawziyyah menarik untuk disimak. Ibn Qayyim mengatakan:

Ulama berpendapat Anda tidak boleh terpaku pada teks-teks yang dikutip dalam kitab-kitab (kuning) sepanjang hidup anda. Jika ada orang asing datang menemui anda menanyakan (iftâ) suatu hukum, anda terlebih dahulu harus menanyai tradisi yang hidup di daerahnya. Sesudah itu baru anda memutuskan ketentuan hukumnya berdasarkan hasil analisis anda terhadap tradisi itu, bukan berdasarkan kebiasaan daerah tempat tinggal anda dan juga bukan berdasar pendapat (mazhab) yang terdapat dalam kitab-kitab (aliran) anda.

Lihat Syams al-Dîn Abî 'Abd Allâh Muhammad ibn Abî Bakr (dikenal dengan Ibn Qayyim al-Jawziyyah), I'lâm al-Muwaqqi în 'an Rabb al-'Âlâmin, (Kairo: Muthâba'ah al-Islâm, 1980), Jilid. 3, h. 77-78. titik singgung mahar dengan variabel sosial, budaya dan ekonomi cenderung terabaikan.

Fakta titik singgung praktek mahar dengan dinamika kehidupan umat Islam tidak dapat dipungkiri. Mahar sebetulnya memainkan fungsi dan peranan yang sangat penting terutama kaitannya dengan refleksi sosial-kultural dan ekonomi. Perbedaan transliterasi istilah mahr (Arab) ke dalam pakem lokal seperti dower dan dowry (Inggris), jujuran (Banjar), sompa, dui' ménré atau dui balanca (Bugis), uang panaik (Makasar), mahar, pisuka dan ajikrama (Sasak), serta maskawin (Jawa), mengisyaratkan variasi konseptualisasi dan pemaknaannya. Dalam kajian sosial, praktek mahar erat kaitannya dengan struktur sosial. Pada komunitas tertentu, mahar menjadi ekspresi kelas sosial atau penegasan nobilitas satu keluarga. Dulu, dan juga sekarang, di masyarakat Jawa seperti dituturkan oleh Geertz, orang tua sering menggunakan pranata mahar untuk revalidasi status sosialnya pada publik. ${ }^{3}$ Untuk tujuan itu, orang tua lazim merayakan pernikahan anak gadisnya secara meriah dan biayanya tidak jarang dibebankan kepada calon mempelai laki-laki dalam bentuk maskawin atau mahar dalam pemaknaan adat setempat.

Mahar dalam studi antropologi-sosiologi bukan tema kajian baru, mengingat pranata mahar melintas batas ruang dan waktu. Banyak penelitian telah dilakukan di bidang ini, bahkan tidak hanya pada komunitas Muslim, tetapi juga komunitas lain seperti Hindu dan Kristen, ${ }^{4}$ baik masyarakat modern ${ }^{5}$ atau yang relatif pramodern. ${ }^{6}$

\footnotetext{
${ }^{3}$ Geertz, The Javanese Family: A Study of Kindship and Socialization, (New York: The Free Press of Glencoe, 1961), h. 45.

${ }^{4}$ Dower pemberian wajib secara hukum dan dowry pemberian wajib menurut adat. Lambiri-Dimaki, "Dowry in Modern Greece: An Institution at the Crossroads between Persistence and Decline" dalam The Marriage Bargain: Women and Dowries in European History, Kaplan, ed., (New York: Havorth Press, 1985), h. 165-78; Carolina, "Hierarchical Women: The 'Dowry' System and Its Implications among Christians in Goa," dalam Contributions to Indian Sociology, Vol. 23 (2) (1989), h. 261-284; Saller, "Roman Dowry and the Devolution of Property in the Principate," dalam Classical Quarterly, Vol. 34 (1), (1984), h. 195-205.

5 Moors, "Women and Dower Property in Twentieth-Century Palestine: The Case of Jabal Nablus," dalam Islamic law and Society, Vol. 1 (3), (1994), h. 301-31; Papps, "The Role and Determinants of BridePrice: The Case of a Palestinian Village," dalam Current Anthropology, Vol. 24 (2), (1983), h. 203-215; Mehdi, "Danish Law and the Practice of Mahr among Muslim Pakistanis in Denmark," dalam International Journal of the Sociology of Law, Vol. 31 (2003), h. 115-129; Chowdhury, "Dowry, Women, and Law in Bangladesh," dalam International Journal of Law and Policy Family, Vol. 24 (2), (2010), h. 198-221.

${ }^{6}$ Stuard, "Dowry Increase and Increments in Wealth in Medieval Ragusa (Dubrovnik)," dalam Journal of Economic History, Vol. 41 (4), (1981), h. 795-811; Guzzetti, "Dowries in Fourteenth-Century Venice," dalam Renaissance Studies, Vol. 16 (4), (2002), h. 430-43; Rodrigues, "For the Honor of Her Lineage and Body: The Dowers and Dowries of Some Late Medieval Queens of Portugal," dalam e-JPH, Vol. 5, (1), (2007), h. 1-13; Reimer, "Women, Dowries, and Capital Investment in Thirteenthcentury Siena", dalam The Marriage Bargain: Women and Dowries in
} 
Dalam kaitan ini, isu mahar dalam konteks sosiologis hukum Islam cukup kompleks karena ia berkelindan erat dengan banyak hal. 'Abd al-Ati merangkum kompleksitas sosio-legal mahar dari perspektif sosialIslam. ${ }^{7}$ Menurutnya, upaya untuk memahami tradisi mahar pada masyarakat Muslim juga harus mencermati konteks sosial-ekonomi, kultural, terutama konstelasi ideologi relasi kelas-kuasa, nilai-nilai keagamaan dan sistem kekerabatan.

Dari gambaran di atas terlihat bahwa pranata mahar tidak sebatas aspek formal hukum. Ia juga terkait erat dengan variabel sosial-ekonomi-kultural. Ringkasnya, deskripsi tersebut memperlihatkan bahwa praktek mahar secara sosiologis dalam masyarakat Muslim tidak dapat dipisahkan dari sejumlah variabel sosial-ekonomikultural. Tulisan ini mengkritisi praktek mahar dalam kaitannya dengan kelas atau status sosial pada beberapa masyarakat Muslim Indonesia yaitu Jawa, Sunda, Betawi, Minang dan Banjar. Studi ini berusaha untuk mengembangkan satu tesis sosiologi hukum bahwa dimensi sosial-ekonomi-kultural sangat inheren dalam dinamika aplikasi pranata mahar, sekaligus menguji hipotesis bahwa praktek mahar berubah mengikuti logika dan tren sosial dan budaya; tren mahar bervariasi menurut variabel daerah, dan tahun; serta mahar berfungsi sebagai indeks status sosial (nobilitas).

\section{Mahar dan Status Sosial \\ Konsep dan Teori}

Mahar adalah satu syarat kesahihan (validitas) pernikahan. Dalam Islam, legislasinya dimaksudkan untuk pemberdayaan perempuan. Alquran tidak memprioritaskan nilai material mahar. Berbeda dengan klaim orientalis, konstruksi fikih mengenai mahar sangat mengapresiasi unsur moral dan juga anasir sosial-ekonomi dan budaya. Diksi shaduqât (jamak, Q.s. al-Nisâ [4]:20) yang lazim diterjemahkan dengan mahar bisa bermakna simbolis dan eksposisif. Secara semantik, kata shaduqah bisa bermakna persahabatan tulus yang disatukan oleh kesucian cinta dan kasih sayang dalam ikatan nilai-nilai ilahiah. Di sini Islam mengajarkan pesan luhur nilai-nilai moral tentang kedalaman hakikat mahar. Mahar bukan harga jual seorang perempuan seperti asumsi yang banyak disalahpahami dalam diskursus sosiologis-antropologis.

Hukum Islam tentang mahar tidak memisahkan dimensi moral dari anasir formal dan sosialnya. Faktanya, praktek mahar di masyarakat Islam cenderung dibiarkan

European History, Kaplan, ed, (New York: Havorth Press, 1985), h. 5979.

7 Al-Ati, The Family Structure in Islam, (Indianapolis: American Trust Publication, 1977), h. 53. lepas berjalan sesuai dengan bingkai dan mekanisme konstruksi sosial-kultural di mana fikih dipraktekkan. Namun hal ini tidak berarti bahwa kitab fikih tidak membahas dan tidak merumuskan jenis dan jumlah mahar. Dalam kaitan ini, Islam hanya meletakkan konsep dan prinsip dasar mahar. Rasulullah Saw. pernah menasehatkan asas normatif mahar bahwa mahar yang baik adalah suatu pemberian yang sederhana, tulus dan tidak memberatkan. ${ }^{8}$ Makna frase "tidak memberatkan" harus dipahami secara kontekstual. Intinya, pemaknaan praksis institusi mahar harus mengakomodasi nilainilai yang hidup di masyarakat dimana dan saat mahar dipraktekkan.

Pelbagai teori sosiologis-antropologis dibangun guna menjelaskan sisi aplikasi mahar. Berbeda dengan visi Islam yang sangat menekankan dimensi moral, teori ekonomi memandang mahar sejenis konpensasi yang harus diberikan suami kepada pihak keluarga istri. Di sini mahar dipahami sebagai ganti-kerugian keluarga untuk biaya pengasuhan anak gadisnya. ${ }^{9}$ Konpensasi harus diberikan karena sebagai aset dan sumberdaya insani keluarga, pengantin perempuan setelah pernikahan akan keluar dari keluarga asalnya, untuk kemudian menjadi anggota dan aset keluarga suaminya.

Pada komunitas lain, mahar dijadikan sebagai investasi dan aset ekonomi untuk jaminan masa depan perempuan. Di masyarakat patrilineal, keluarga lakilaki menjadi tolok ukur status sosial. Karenanya, banyak keluarga perempuan kelas bawah berhasrat menikahkan anak gadisnya dengan laki-laki kelas atas (marry up) untuk hajat mobilitas sosial. Di sini, mahar diberikan oleh keluarga perempuan kepada keluarga suami untuk meraih status kelas sosial yang lebih baik, seperti tradisi yang lumrah dipraktekkan di belahan anak benua Asia Selatan, India, Pakistan dan Bangladesh, walau dalam prakteknya, mahar secara statistik belum memadai untuk memberi jaminan sosial-ekonomi bagi perempuan. ${ }^{10}$

Institusi mahar dalam sistem kasta telah direformasi secara hukum di India karena ia banyak dan sering

${ }^{8}$ Zahrah, Membangun Masyarakat Islami, diterjemahkan oleh Shodiq Noor Rahmat, (Jakarta: Pustaka Firdaus), h. 82; As-Samaluthi, Pengaruh Agama terhadap Struktur Keluarga, diterjemahkan oleh Anshori Umar Sitanggal, (Surabaya: Bina Ilmu, 1991), h. 216.

9 Lihat Anderson, "The Economics of Dowry and Brideprice," dalam Journal of Economic Perspectives, Vol. 21 (4) (2007), h. 151-174; Gray, "Sonjo Brideprice and the Question of African 'Wife Purchase," dalam American Anthropologist, Vol. 62 (1), (1960), h. 34-47; Kressel, "Brideprice Reconsidered," dalam Current Anthropology, Vol. 18 (3), (1977), h. 441-58.

${ }^{10}$ Rao, "Dowry Inflation' in Rural India: A Statistical Investigation," dalam Population Studies, Vol. 47 (2), (1993), h. 283-293; Rao dan Rao, "The Dowry System in Indian Marriages: Attitudes, Expectations and Practices," dalam International Journal of Sociology of the Family, Vol. 10, (1980), h. 99-113; Nishimura, "Marriage Payments among 
berefek buruk kepada perempuan. Pemerintah kolonial Inggris telah menghapus beberapa bagian hukum mahar ini. ${ }^{11}$ Di India, semakin tinggi kasta seorang laki-laki, semakin besar jumlah mahar yang harus diberikan kepada keluarganya. Pada tradisi ini, keluarga perempuan sering nekat membayar mahar yang mahal pada keluarga pengantin laki-laki yang berasal dari kasta tinggi. Tujuannya adalah untuk menggapai kasta yang tinggi untuk perempuan, mengingat sistem kasta-kelas sosial India dinisbatkan pada keluarga laki-laki. Namun sistem "pembelian suami" dalam format pembayaran mahar yang tinggi justru memenjarakan perempuan dalam penderitaan panjang. ${ }^{12}$ Dengan asal usul status kasta yang lebih rendah, perempuan dalam format perkawinan ini sering mengalami beragam kekerasan psikologis dan juga penyiksaan fisikal. Bahkan penyiksaan tersebut dibenarkan dan sangat kental dilindungi oleh tradisi.

Menurut al-'Ati, penekanan aspek ekonomi mahar tidak relevan dalam Islam. Ide ini tidak beralasan. Sejarah legislasi mahar dalam Islam tidak mengutamakan dimensi ekonomi. Banyak fakta historis yang menguatkan sinyalemen ini, seperti kasus pernikahan putri Rasulullah Saw. dan 'Ali ibn Abû Thâlib Ra (w. 40 H/661 M). Ada dua alasan mendasar untuk menganulir validitas asumsi ekonomi mahar dalam tradisi Islam, yaitu: (1) Berbeda dengan tradisi era pra-Islam, mahar dalam ajaran Islam menjadi aset dan hak pribadi perempuan. Di sini perempuan dapat bertindak bebas terhadap

the Nagarattars in South India," Contributions to Indian Sociology, Vol. 28 (3), (1994), h. 243-272; Dalmia dan Lawrence, "The Institution of Dowry in India: Why It Continues to Prevail," dalam Journal of Developing Areas, Vol. 38 (2), (2005), h.71-93; Amin dan Cain. "The Rise of Dowry in Bangladesh" dalam The Continuing Demographic Transition, Jones, et.als. eds. (Oxford: Oxford University Press, 1997), h. 290-306; Huq and Amin, "Dowry Negotiations and the Process of Union Formation in Bangladesh: Implications of Rising Education," Unpublished Manuscript, 2001; Suran, at.al, "Does Dowry Improve Life for Brides? A Test of the Bequest Theory of Dowry in Rural Bangladesh," Policy Research Division Working Paper No. 195, (Population Research Council, Inc., (2004), h. 2-28.

${ }^{11}$ Sandanshiv dan Mathew. "Legal Reform in Dowry Laws," dalam Kalis Yug: Empowerment, Law and Dowry Death, Jethmalani, ed. (New Delhi: Har-Anand, 1995), h. 79-93; Gupta, "Women's Human Rights and the Practice of Dowry in India; Adapting A Global Discourse to Local Demands," dalam Journal of Legal Pluralism, Vol. 48, (2003), h. 85-123.

${ }^{12}$ Bloch dan Rao. "Terror as a Bargaining Instrument: A case Study of Dowry Violence in Rural India," dalam The American Economic Review, Vol. 92 (4), (2002), h. 1029-1043; Stone dan James "Dowry, Bride Burning and Female Power in India", dalam Gender in Cross-Cultural Perspectives, Brettell dan Sargent, eds., (New Jersey: Prentice Hall, 1997), h. 270-79; Kumari, Brides are Not for Burning. Dowry Victims in India. (Radiant Publishers, 1989); Oldenburg, "Dowry Murders in India: A Preliminary Examination of the Historical Evidence", dalam Women's Lives and Public Policy: The International Experience, Turshen, eds, (Westport, CT: Greenwood Press, 1993), h. 145-157. maharnya sejauh dilakukan atas dasar prinsip Islam. (2) Islam mengizinkan mahar dengan limit ekonomi yang sangat minimal, setara harga seutas cincin murahan. Jika mahar dipahami secara ekonomis seperti keyakinan Levy, pemberian 'Ali berupa seutas cincin besi kepada Fatimah Ra (w.11 H/634 M), putri Rasulullah Saw., sebagai mahar pernikahannya tentu tidak memiliki nilai ekonomis. Intinya, mahar menurut ajaran Alquran tidak sebatas aspek ekonomi. Ia secara instrumental menjadi simbol kejujuran, ketulusan cinta dan kasih sayang yang mengikat hati dua insan dalam pernikahan.

Walaupun demikian, namun aspek ekonomi mahar tidak dilarang dalam Islam. Merujuk Alquran (Q.s. al-Nisâ [4]: 20), perempuan boleh meminta apa saja untuk mahar. Di sejumlah komunitas Islam yang kuat menjaga status sosial keluarga besar, mahar ditakar berdasarkan standar ekspresi kebanggaan pamer status sosial. Akibatnya mahar bisa saja sangat mahal bahkan tidak terjangkau kemampuan standar umum. Tradisi mahar yang mahal tentu mengundang pro-kontra, simpati, apriori, bahkan apatisme. Tetapi ini adalah fakta mahar di komunitas Muslim seperti Aceh, Bugis, Arab, Sasak, Banjar dan Melayu. ${ }^{13}$ Bahkan norma fikih yang diadopsi Kompilasi Hukum Islam di Indonesia (Pasal 35 ayat 3) juga menjadikan standar kelaziman lokal untuk penyelesaian kasus perselisihan jumlah mahar yang harus dibayarkan suami.

Mahar secara sosial, ekonomi dan ideologis, difungsikan untuk beragam tujuan. ${ }^{14}$ Abû Zahrah menjelaskan bahwa selain menjadi tanda etis-moral keseriusan dan ketulusan ikatan pernikahan, mahar berfungsi sebagai bantuan material suami kepada istrinya guna persiapan berumah tangga. ${ }^{15}$ Namun mahar juga dijadikan sebagai alat kontrol kekuasaan berupa tetapnya otoritarianisme suami untuk mentalak istrinya. Hukum talak Islam mewajibkan suami yang telah menggauli istrinya secara seksual untuk membayar keseluruhan mahar. Dengan ikatan, tepatnya beban mahar, suami diharapkan lebih bijak jika berniat menceraikan istrinya. Di sisi lain, mahar juga digunakan sebagai pencipta pelbagai media relasi sosial. Via instrumen mahar, jejaring relasi sosial baru dapat terbangun secara meluas dan dapat difungsikan sebagai ikatan khusus untuk mempererat

${ }^{13}$ Haderiva, Kajian terhadap Pemberian Mahar yang Tinggi pada Masyarakat Adat Bugis di Kota Sebatik; Ditinjau dari Hukum Islam (Studi Kasus di Kecamatan Sebatik, Kabupaten Nunukan, Kalimantan Timur, Skripsi, (Universitas Muhammadiyah Malang: Fakultas Agama Islam, 2006).

14 Arunachalam dan Logan, "On the Heterogeneity of Dowry Motives," National Bureau of Economic Research, Working Paper 12630, (2006).

${ }^{15}$ Zahrah, Membangun Masyarakat Islami, h. 81. 
tali perbesanan (semenda, mushâharah). ${ }^{16}$

Jumhur fukaha secara aklamatif menyepakati bahwa mahar wajib diberikan suami kepada istrinya. Banyak ayat Alquran dan rangkaian Hadis dengan jelas menegaskan hal ini. Tidak ada dispute atau perbedaan pendapat di kalangan fukaha tentang kewajiban pembayaran mahar kepada pengantin perempuan. Namun waktu penyerahan, terutama jenis dan jumlahnya, merupakan hasil negosiasi dan kesepakatan suami dan istri dengan mempertimbangkan nobilitas keluarga istri. Rasulullah Saw. dalam sebuah Hadis sahih al-Bukhârî, Bab Nikah, nomor 51, menjelaskan bahwa mahar dapat berwujud materi (uang, perhiasan, properti dan benda lainnya), jasa pengajaran Alquran dan dapat juga berwujud perpaduan semuanya.

Penetapan jenis dan jumlah mahar, seperti di masyarakat Muslim Banjar, bisa berjalan alot dan berakhir dramatis. Proses tawar menawar jumlah mahar (dalam bahasa Banjar disebut bapintaan) biasa terjadi saat proses melamar. Banyak kasus pertunangan yang diputus hanya karena tidak tercapai kesepakatan besaran mahar. Di masyarakat tertentu, jenis dan jumlah mahar dapat ditetapkan secara sepihak oleh keluarga perempuan. Secara total, satu norma kunci dalam konteks ini bahwa mahar, secara sosiologis, harus disesuaikan dengan kondisi status sosial dan ekonomi keluarga istri. Hal ini penting mengingat jumlah mahar yang terlalu rendah dapat menyinggung perasaan mereka. Sebaliknya, jumlah mahar yang terlalu mahal bisa membuat banyak laki-laki mengurungkan niatnya untuk melamar gadis pujaannya.

Selain uang, mahar juga dapat berwujud aset tidak bergerak, peralatan rumah tangga, pakaian, perhiasan bahkan dalam wujud jasa pengajaran Alquran atau agama. Belakangan, tren praktek mahar mengalami pergeseran, dari uang atau objek yang bernilai praktis ke benda yang bernuansa simbol agama dan penampilan, dari uang ke aset/properti tidak bergerak dan dari uang ke perhiasan. Bahkan, akhir-akhir ini, tren praktek mahar semakin bergeser. Seiring dengan tren romantisisme dan spiritualisasi pernikahan sebagai institusi sakral, tradisi mahar mengalami perubahan mendasar. Mahar tidak lagi dipersepsikan secara material, tetapi ia lebih dipahami dan ditempatkan pada posisi simbol penampilan, kesucian dan ketulusan relasi laki-laki dan perempuan. Karenanya, benda-benda tertentu (cincin, kalung permata, berlian, mutiara dan jenis perhiasan lainnya, bahkan intan), cenderung dijadikan alternatif mahar sebagai simbol gengsi penampilan dan ketulusan tersebut. Sementara

${ }^{16}$ As-Samaluthi, Pengaruh Agama terhadap Struktur Keluarga, h. 210. itu perangkat alat shalat dan Alquran bahkan paket umroh/haji serta pengajaran baca tulis Alquran kepada calon mempelai perempuan sering dijadikan mahar. Jenis objek mahar tersebut dipilih karena ia dipahami sebagai simbol religius yang diharapkan dapat melanggengkan pernikahan. Alhasil, tren mahar sedikit banyak telah mengalami perubahan.

Beberapa studi empiris dan normatif tentang mahar telah dilakukan dengan beragam fokus. Rumpun studi pertama banyak menyoroti titik singgung mahar dengan faktor ekonomi kehidupan perempuan. Anderson dan sejumlah ilmuwan ekonomi secara khusus mengkritisi fungsi ekonomi mahar bagi perempuan untuk jaminan masa depannya, juga untuk keluarga besarnya. ${ }^{17}$ Rumpun kedua mencermati mahar dan status atau kelas. ${ }^{18}$ Rumpun penelitian ketiga mencermati sisi negatif mahar terutama titik singgungnya dengan kekerasan terhadap perempuan. Kajian ketiga ini banyak dimotori oleh aktivis advokasi perempuan. ${ }^{19}$ Model studi keempat cenderung mengkritisi normativitas mahar. ${ }^{20}$ Sementara kelompok studi terakhir mencermati penerapan mahar di ranah pengadilan. ${ }^{21}$

\footnotetext{
${ }^{17}$ Anderson, "Why Dowry Payments Declined with Modernization in Europe but Are Rising in India," dalam Journal of Political Economy, Vol. 111 (2), (2003), h. 269-310; Afzal dan Subhani, To Estimate an Equation Explaining the Determinants of Dowry, Iqra University (2009); Heyer, "The Role of Dowries and Daughters' Marriages in the Accumulation and Distribution of Capital in a South Indian Community," dalam Journal of International Development, Vol. 4 (4), (1992), h. 419-436; Saroja dan Chandrika "Income and Dowry: Some Revealing Connections," dalam Indian Journal of Social Work, Vol. 52 (April), (1991), h. 205-213; Rao, "The Rising Price of Husbands: a Hedonic Analysis of Dowry Increases in Rural India," dalam Journal of Political Economy, Vol. 101, (1993), h. 666-677.

${ }^{18}$ Korson, "The Roles of Dower and Dowry as Indicators of Social Change in Pakistan," dalam Journal of Marriage and the Family, Vol. 30 (4), (1968), h. 696-707; Korson, "Dower and Social Class in an Urban Muslim Community," dalam Journal of Marriage and the Family, Vol. 29, (3) (1967), h. 527-533

${ }^{19}$ Greenberg, "Criminalizing Dorwy Deaths; The Indian Experience," dalam Journal of Gender, Social Policy and the Law, Vol. 11 (2) (2003), h. 801-846; Rudd, "Dowry-Murder: An Example of Violence against Women," dalam Women's Studies International Forum, Vol. 24, (5), (2001), h. 513-522.

${ }^{20}$ Wani, the Islamic Institution of Mahr; A Study of Its Philosophy, Working and related Legislations in the Contemporary World, (Kashmir: Upright Study Home, 1996); Siddiqui, "Mahr: Legal Obligation or Rightful Deman?" dalam Journal of Islamic Studies, Vol. 6 (1), (1995), h. 14-24; Freeland, "The Islamic Institution of Mahr and American Law," dalam Gonzaga Journal of International Law, Vol. 4 (I) (2000-01); Singh, "Law of dower (Mahr) in India," Journal of Islamic Law and Culture, Vol. 12, (1), (2010), h. 58-73.

21 Sitaraman, "Law as Ideology:Women, Courts and 'Dowry Deaths' in India," dalam International Journal of the Sociology of Law, Vol. 27, (1999), h. 287-316; Fournier, "Flirting with God in Western Secular Courts: Mahr in the West," dalam International Journal of Law, Policy and the Family Vol. (2009), h. 1-28; Blenkhorn, "Notes: Islamic Marriage Contracts in American Courts: Interpreting Mahr Agreements as Prenuptials and Their Effect on Muslim Women," dalam Southern California Law Review, Vol. 76 (2002), h. 189-234.
} 
Beberapa hasil studi di atas dapat diringkas bahwa dari aspek ekonomi, negosiasi mahar untuk jumlah yang besar dimaksudkan untuk menjaga dan menjamin stabilitas kehidupan perempuan, terutama di saat terjadi perceraian dan suami mengabaikan kebutuhan biaya hidup anakanak dan mantan istrinya. ${ }^{22}$ Walaupun tidak signifikan, dimensi ekonomi ini sedikit banyak berfungsi positif memberi perlindungan kepada perempuan. Tetapi detail studi Anderson juga mencatat sisi negatif mahar bagi perempuan. Analisis statistik multivariat menunjukkan bahwa mahar terbukti tidak bisa berfungsi maksimal untuk meningkatkan taraf kesejahteraan ekonomi perempuan. Bahkan pengaruh mahar terhadap mobilitas ekonomi perempuan tidak lebih dominan dibanding efek pendidikan dalam kasus yang sama.

Praktek mahar yang mahal mengesankan transaksi diri dan hidup perempuan. Ada sisi negatif dari praktek kontraktual mahar ini. Di sini suami merasa telah membeli istrinya via piranti pembayaran mahar. Penyikapan patriarkis ini berdampak negatif terhadap kehidupan perempuan. Studi di India mencatat bahwa mahar lazim mengakibatkan kekerasan terhadap istri. Menurut catatan pegiat gender, angka kematian istri akibat mahar yang tinggi naik 38\% dan kasus penyiksaan serta pelecehan yang bersumber dari mahar naik 225\%. Di India, pada tahun 1998 sebanyak 4.836 perempuan meninggal dunia akibat kejahatan berbasis praktek mahar yang memberatkan. Angka ini naik drastis menjadi 6.699 pada tahun 1999.23

Di Indonesia, kekerasan terhadap perempuan berbasis praktek mahar terekam dalam banyak hasil studi. Sistem bajapuik dalam adat Minangkabau, yang awalnya diharapkan dapat memproteksi perempuan, terbukti tidak selamanya berhasil. ${ }^{24}$ Menurut studi Azwar, materi/ aset uang jemputan, yang awalnya untuk hajat perempuan, dalam prakteknya jatuh dalam dominasi penguasaan lakilaki. Di sini akses perempuan untuk memanfaatkan aset

${ }^{22}$ Esteve-Volart, 2004. "Dowry in Rural Bangladesh: Participation as Insurance against Divorce," Unpublished paper. (diunduh dari http:// dept.econ.yorku.ca/\%7Eberta/dowry_web.pdf); Upadhya, "Dowry and Women's Property in Coastal Andhra Pradesh," dalam Contributions to Indian Sociology, Vol. 24 (1), (1990), h. 29-59; Anderson, Dowry and Property Rights, Department of Economics, University of British Columbia, Canada, (August 2004); Tambiah, "Dowry and Bridewealth and the Property Rights of Women," dalam Bridewealth and Dowry, Goody dan Tambiah, eds. (London: CambridgeUniversity Press, 1973), h. 45 .

${ }^{23}$ Bumiller, May You Be the Mother of A Hundred Sons, (New Delhi: Penguin, 1992), h. 44-74; Sirohi, Sita's Curse, Stories of Dowry Victims, (New Delhi: HarperCollin Publishers India, 2003), h. 35.

${ }^{24}$ Dalam tradisi Bajapuik Pariaman Sumatera Barat, pihak perempuan membayar uang-materi (sejenis mahar) kepada calon suaminya. Semakin tinggi status sosial suami, semakin banyak jumlah materi pembayaran. Azwar, Matrilokal dan Status Perempuan dalam Tradisi Bajapuik, (Yogyakarta: Galang Press, 2001), h. 5. mahar sangat terbatas. Budaya patriarkis adalah faktor yang paling bertanggungjawab terhadap penyelewengan konsep ideal ini. Sebetulnya penyimpangan konsep ideal mahar juga terjadi hampir di setiap komunitas dengan variasi faktor pemicu dan pelestarinya. Tetapi realitas hukum yang baik selalu saja menyimpan wajah yang kontradiktif yaitu penyimpangan.

Lebih tragis adalah kasus pembenaran penyiksaan terhadap istri atas dasar pembelian istri dengan mahar. Ribka melaporkan bahwa dalam dialog singkat antara hakim dengan suami yang digugat cerai istrinya terekam rangkaian frase kalimat vulgar berikut: "Apakah saudara sayang istri (?) Jika ya, mengapa kau sia-siakan dia?", tanya seorang hakim di satu pengadilan Jakarta. "Dia istri saya, milik saya! Saya sudah beli dia melalui pernikahan. Saya mau bikin permaisuri atau pembantu, itu hak saya", Jawab suami yang bertitel insinyur. "Bagaimana caranya kamu memukul istrimu?", lanjut hakim. "Saya memukulnya dengan tangan, yaitu menampar ke arah wajahnya. Itu saya lakukan sebab (dia) sudah keterlaluan. (S) ekarang dia tidak bisa diatur", jawab sang suami yang temperamental. ${ }^{25}$

Sementara itu studi Korson memotret titik singgung yang signifikan antara praktek mahar dan status sosial. Ada korelasi positif antara besaran mahar dengan status sosial keluarga perempuan. Komunitas kelas atas lebih mengapresiasi tradisi mahar yang tinggi dibanding warga kelas bawah. Pendukung tradisi mahar tidak berbeda menurut usia, tetapi mereka terikat dengan faktor kelas sosial. Intinya, perbedaan usia tidak berpengaruh signifikan terhadap persepsi mengenai mahar. Jika perbedaan generasi menunjukkan perubahan waktu, tetapi respon sosial terhadap tradisi mahar di Pakistan tidak berubah signifikan dari waktu ke waktu. Ini artinya bahwa tradisi mahar telah dan terus mendarah daging atau lekat dalam tradisi masyarakat lokal.

Status sosial merupakan indikator utama untuk level nobilitas seseorang. Status sosial adalah kumpulan hak dan kewajiban yang dimiliki individu di masyarakat yang berfungsi sebagai tolok ukur posisi sosialnya di ranah strata sosial. Individu dengan status sosial yang tinggi akan ditempatkan lebih tinggi dalam struktur sosial dibanding orang yang berstatus sosial rendah. Dalam kajian sosiologi, indikator utama status sosial dan ekonomi adalah tingkat pendidikan, pekerjaan dan penghasilan. ${ }^{26}$ Ketiga faktor ini terbukti selalu berkorelasi

${ }_{25}$ Ribka, Tindak Kekerasan terhadap Perempuan dalam Keluarga, Tesis Master, (Jakarta: Program Studi Kajian Wanita, Pascasarjana, Universitas Indonesia, 1988), h. 48-49.

${ }^{26}$ Untuk deskripsi detail tentang stratifikasi, lihat Grusky, Social Stratification: Class, Race, and Gender in Sociological Perspective, (Boulder, 
positif sebagai indikator yang serumpun untuk menilai tingkat status sosial.

Merujuk gambaran di atas, konsep status sosial dan ekonomi yang diterapkan dalam studi ini hanya mencakup aspek pekerjaan dan pendidikan pengantin laki-laki, perempuan dan orang tuanya, karena data tentang penghasilan tidak tersedia dalam catatan buku besar data base pernikahan yang menjadi sumber data studi ini. Selain itu, buku pencatatan perkawinan tidak mendokumentasi data tingkat pendidikan kedua pengantin secara lengkap. Ada variasi kebijakan per daerah dalam pencatatan kelengkapan data pendidikan dan pekerjaan. Sejak tahun 1992, sejumlah Kantor Urusan Agama (KUA) tidak mencatat data pendidikan pengantin dan data pekerjaan orang tua pengantin. Namun jumlah sampel pernikahan yang sangat banyak dalam studi ini diharapkan dapat mengatasi titik kekurangan data di atas.

\section{Data dan Metode Penelitian}

Penelitian ini adalah studi eksploratif-eksplanatoris, yaitu bermaksud untuk menggali dan menjelaskan faktor sosial-ekonomi yang terkait dengan praktek mahar di komunitas Muslim. Analisis lebih menekankan model pembacaan data secara kuantitatif. Beragam model uji statistik digunakan untuk menelisik detail hasil penelitian ini, terutama untuk melihat variasi praktek mahar menurut variabel analisis dan menjelaskan korelasi variabel sosial-ekonomi dengan tren praktek mahar.

Data studi bersumber dari buku besar pencatatan perkawinan di beberapa KUA sampel wilayah penelitian. Karena fokus studi adalah menjelaskan tradisi mahar dalam lintasan waktu, time series data yang digunakan dimulai tahun 1970 sampai 2008 (selama 38 tahun). Sampel menurut daerah dan tahun bervariasi, serta diseleksi secara insidental dengan jumlah 7.721 kasus. $^{27}$ Walaupun secara metodologis data studi ini masih memiliki keterbatasan, namun jumlah sampelnya secara statistis sangat banyak baik dari segi waktu maupun tempat.

Status sosial diukur berdasarkan jabatan yang dipangku seseorang dalam pekerjaan. Untuk analisis, kelas sosial dipilah menjadi (1) kelas atas, (2) menengah dan (3) bawah. Setiap kelas dirinci ke dalam sub kelas. ${ }^{28}$

Colorado: Westview Press Inc., 1994); Sujatmiko, "Stratifikasi Sosial dan Mobilitas Sosial," dalam Jurnal Sosiologi Indonesia, No. 1, (1996).

${ }^{27}$ Sumatera Barat 4,1\% (320 kasus), DKI Jakarta 61,7\% (4.766 kasus), Jawa Barat 25,9\% (1.995 kasus), Banten 4,7 \% (360 kasus) dan Kalimantan Selatan 3,6\% (280 kasus).

${ }^{28}$ Kelas Atas mencakup menteri, perwira TNI/polisi, gubernur, pejabat eselon 1, anggota DPR/D, direktur utama, bupati/walikota, diplomat tinggi, pejabat eselon 2. Kelas Menengah dipisah menjadi
Level pendidikan dipilah menjadi 7 kategori, yaitu (1)

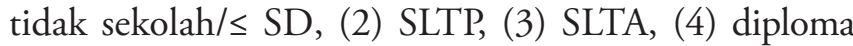
1-2, (5) diploma 3/BA, (6) Strata 1, dan (7) Strata 2/3/pendidikan profesi. Variabel status marital dipilah berdasarkan jenis kelamin. Untuk laki-laki, status marital dipilah menjadi jejaka, duda (cerai hidup-mati) dan beristri. Sedangkan untuk perempuan, status marital dipisah menjadi gadis dan janda.

Variabel jenis mahar dipilah menjadi (1) uang, (2) perhiasan, (3) simbol agama (Alquran, perangkat shalat, buku agama, pengajaran agama/baca-hafal-tulis Alquran dan haji/umroh, (4) properti yang mencakup rumah, tempat usaha, tanah, dan sawah, (5) pakaian, peralatan dan perabot rumah tangga (mesin jahit, jam, tempat tidur, lemari, perabot rumah lainnya, radio dan televisi) dan (6) kombinasi beragam jenis mahar di atas. Perhiasan emas diukur menurut standar gram. Sedangkan mahar perhiasan non emas tidak dianalisis karena jumlah kasusnya terlalu sedikit. Selain itu, variasinya berimplikasi pada perbedaan nilai ekonomis yang sulit untuk diukur.

Mahar uang diukur berdasarkan rupiah. Analisis kuantitatif terhadap besaran mahar uang lintas waktu sedikit banyak menghadapi kesulitan. Dalam catatan KUA, mahar uang dibayar dalam bentuk rupiah. Karena nilai rupiah sangat fluktuatif di pasar uang menurut tahun, nilai rupiah dikonversi ke dollar USA. Pilihan ini didasarkan pada konsep mata uang dunia yang menjadikan dollar USA sebagai mata uang yang tidak pernah dan tidak akan pernah didevaluasi. Jadi nilai dollar akan stabil dalam lintasan waktu. Nilai dollar terhadap rupiah ditentukan berdasarkan rata-rata harga rupiah yang beredar dan berkembang setiap awal tahun. Sementara kuantitas mahar perhiasan emas tetap diukur menurut satuan gram.

\section{Profil Sampel}

Profil status marital sampel menampilkan informasi yang menarik. Mayoritas istri $(84,8 \%)$ saat pernikahan berstatus gadis. Hanya 77,4 \% suami masih berstatus jejaka dan selebihnya (22,6 \%) berstatus pernah

(a) Menengah-atas mencakup arsitek, dokter, hakim, akuntan, camat, pejabat eselon 3, diplomat biasa, dosen, pengacara, jaksa, direktur; (b) Menengah-bawah mencakup pejabat eselon 4, wartawan, pegawai BUMN/D (biasa), manajer, PNS, lurah/kepala desa, apotiker, bidan, perawat, guru SLTA/SLTP, pensiunan PNS/TNI/polisi, pedagang menengah, seniman/artis, penceramah "berkelas". Kelas Bawah dipisah menjadi (a) Bawah-atas mencakup sopir, masinis, mandor, teknisi, montir, tukang ojek, guru agama biasa, penjahit dan karyawan; (b) Bawah-bawah yang mencakup tenaga keamanan (satpam), petani, buruh, tukang, pembantu rumah tangga, tukang becek, tukang cukur, pesuruh, pelayan warung-toko, tukang kebun, pelaut/nelayan dan kondektur/kenek. 
menikah, baik duda atau sedang beristri. Mayoritas $(92,3 \%)$ pernikahan adalah monogami dan sisanya 7,7 $\%$ adalah poligami.

Tren usia pengantin laki-laki dan perempuan sangat berbeda. Mereka cenderung menikah di usia yang cukup muda. Usia suami lebih tua dibanding usia istri. Ratarata usia pengantin laki-laki adalah 25,97 tahun dengan standar deviasi (SD) 7,13 tahun. Rata-rata usia pengantin perempuan adalah 20,98 tahun (SD 4,99 tahun). Besarnya angka standar deviasi di atas memperlihatkan variasi usia pernikahan yang ekstrim di kalangan sampel, terutama di kelompok laki-laki. Ada sampel yang menikah di usia yang cukup tua dan ada banyak perempuan pada usia yang sangat muda sudah menikah. Usia minimum suami 15 tahun dan istri 13 tahun, sedangkan usia maksimum suami 83 tahun dan istri hanya 55 tahun.

Usia menjadi faktor penting dalam seleksi calon pasangan. Laki-laki selalu memilih istri yang berusia lebih muda. Perempuan secara fisikal memang lebih cepat terlihat lebih tua dibanding laki-laki. Namun perbedaan usia, oleh laki-laki, sering dijadikan senjata, minimal alat kontrol ideologis untuk menciptakan dependensi istri pada suami. Bahkan ilmu psikologi menganggap satu penyimpangan jika seorang laki-laki mencintai perempuan yang berusia lebih tua (tragedi oedipus complex). Bukti sinyalemen psikologis sangat menonjol dalam studi ini. Hanya sebagian kecil laki-laki menikahi perempuan yang berusia lebih tua, bahkan jika terjadi perbedaan usia, perbedaan usia mereka tidak mencolok. Misalnya, sekitar dua pertiga laki-laki berusia 31-35 tahun menikahi perempuan berusia $\leq 25$ tahun. Bahkan 4,4 \% laki-laki berusia $\geq 36$ tahun masih lazim menikahi perempuan berusia $\leq 20$ tahun.

Tingkat pendidikan sampel tidak rendah, yaitu: (1) $69 \%$ sampel suami dan $62 \%$ istri menamatkan pendidikan minimal level SLTA. Bahkan minimal 28 $\%$ suami dan istri menamatkan satu jenjang pendidikan tinggi. (2) Level pendidikan istri umumnya lebih rendah dibanding dengan jenjang pendidikan suami. Selain itu, hanya 9,7\% laki-laki menikahi pasangan yang berpendidikan lebih tinggi darinya (marry up). Sebaliknya, perempuan sangat langka menikah dengan laki-laki yang berpendidikan lebih rendah (marry down). ${ }^{29}$ Pola ini merata di setiap level pendidikan. Bahkan semakin tinggi tingkat pendidikannya, laki-laki semakin jarang menikahi pasangan yang berpendidikan

${ }^{29}$ Bambawale dan Ramanama, "Mate Selection in Inter-Religious Marriages: An Indian Perspective," dalam Indian Journal of Social Work, Vol. 42, (2) (1981), h. 165-173; Martin, "A Comment on Whether American Women Do Marry Up," dalam American Journal of Sociology, Vol. 35, (1972), h. 237. lebih tinggi. Hal ini nampaknya terkait erat dengan kesadaran ideologi superioritas laki-laki yang selalu tidak mau berpasangan hidup dengan perempuan yang melebihi keberadaannya.

Ada sisi keunikan profil status sosial suami dan istri dalam studi ini. Suami (68\%) dan istri (82\%) umumnya berasal dari keluarga kelas bawah. Lebih spesifik, walaupun prinsip kafâah (kesetaraan, keserupaan dan keserasian) menjadi kriteria memilih pasangan, laki-laki cenderung tidak mencari istri yang berlatar kelas sosial yang setara atau lebih darinya. Data menunjukkan bahwa status sosial laki-laki cenderung lebih tinggi dibanding dengan status sosial perempuan.

Sisi lain bahwa seseorang cenderung mencari calon pasangan yang mempunyailatar belakang sosial, kultur dan struktur pekerjaan yang serumpun dengan pekerjaannya. Anak petani cenderung menikahi pasangan dari keluarga petani, keluarga pedagang menikahkan anaknya dengan keluarga pedagang, keluarga buruh menikahi anggota keluarga buruh atau individu yang sederajat dengannya dan pegawai negeri menikahi pegawai negeri. Tradisi ini akan melembagakan hegemoni kultur tradisional yang sangat tipikal dalam keluarga dan sekaligus menghambat proses akselerasi mobilitas sosial via proses pernikahan lintas suku dan status sosial. Intinya, institusi pernikahan masih menjadi mesin sosial-kultural utama untuk melestarikan tradisionalisme di masyarakat Islam. Dengan kata lain, mobilitas, transformasi dan alih pekerjaan via jalur proses pernikahan nampaknya sulit diharapkan.

\section{Temuan Penelitian \\ Tren Praktek Mahar}

Di bagian awal disajikan jenis mahar yang diberikan dalam pernikahan dan berturut-turut akan disajikan jenis mahar dalam kaitannya dengan beberapa variabel analisis. Ada dua model mahar yang dominan dipraktekkan dalam studi ini, yaitu: (1) Tradisi mahar dalam wujud perhiasan dan uang $(79 \%)$ sangat kental dalam praktek pernikahan; (2) $17 \%$ mahar berwujud simbol agama (alat shalat, kitab suci, buku agama dan ritus keagamaan). Selebihnya, 2,4\% mahar dalam wujud properti, pakaian dan peralatan rumah tangga tanpa dipadu dengan ketiga jenis pertama mahar di atas. Gejala penggunaan simbol agama untuk mahar dalam penelitian ini sangat berbeda dengan fenomena yang serupa di Kalimantan Selatan. ${ }^{30}$ Di sana, komunitas Muslim,

${ }^{30}$ Aini, "Mahar dalam Konteks Sosial-Budaya Muslim; Mahar dan Status Sosial dalam Kehidupan Masyarakat Amuntai, Kalimantan-Selatan," dalam Khazanah: Majalah Ilmiah Keagamaan dan Kemasyarakatan, Vol.1 (6), (2002). 
terutama pra 1990-an, tidak terbiasa menggunakan objek simbol agama untuk dijadikan mahar.

Tren jenis mahar bervariasi menurut sejumlah variabel, yaitu: (1) Tren penggunaan objek simbol agama untuk mahar semakin dominan tahun 1990-an dan 2000-an. Sebaliknya, tren mahar uang yang tinggi semakin tidak populer. (2) Tren jenis mahar ini bervariasi menurut daerah penelitian. Mahar uang tidak populer di Sumatera Barat dan Jakarta. Sebaliknya, mahar simbol agama sangat populer $(70 \%)$ di Sumatera Barat, namun model ini tidak begitu lazim di daerah lain. Mahar dalam wujud perhiasan umumnya tidak lazim $(<17 \%)$ di semua daerah penelitian, kecuali di Jakarta (42\%). Perbedaan dan perubahan tren mahar jenis ini signifikan (p. <.01) menurut faktor daerah atau tahun. Ringkasnya, tren jenis mahar berkaitan erat dengan pengaruh tradisi dan budaya yang berkembang di daerah penelitian.

Adapun jumlah mahar dalam wujud uang dan perhiasan yaitu: (1) Besaran mahar dalam wujud uang (dollar) sangat bervariasi. Rata-rata besaran mahar uang berjumlah \$16,71 (SD \$ 80,45). Satu fakta yang unik bahwa ada mahar uang dengan nilai minimum kurang dari satu dollar. Dan sebaliknya, ada nilai maksimumnya mencapai \$2.565. (2) Rata-rata mahar perhiasan berjumlah 9,3 gram (SD 9,35 gram). Nilai minimum mahar perhiasan $1 / 2$ gram dan maksimum mencapai 105 gram. Ini artinya bahwa ada variasi yang signifikan dalam praktek jumlah mahar di masyarakat. Ada warga masyarakat yang memberi mahar uang atau perhiasan dalam jumlah yang sangat besar, sementara yang lainnya hanya memberi mahar dalam jumlah yang sangat sedikit, sebatas untuk memenuhi standar formalitas atau untuk makna yang lain. Perbedaan ini nampaknya terkait dengan model pemaknaan mahar dalam kehidupan umat Islam, terutama terkait dengan variabel status sosial. Misalnya bagi warga perkotaan, jumlah uang mahar lazim tidak dimaksudkan untuk nilai nominal. Faktanya, jumlah uang sering hanya dikaitkan dengan tanggal, bulan dan tahun pernikahan, atau sebatas hanya untuk mencatat momentum pernikahan. Sebaliknya, banyak orang desa menjadikan mahar sebagai modal hidup keluarga baru dan untuk biaya pernikahan.

\section{Mahar dan Status Sosial}

Studi ini bermaksud menguji korelasi praktek mahar dengan beberapa variabel sosial, maka hasilnya yaitu: (1) Jenis mahar uang, perhiasan dan simbol agama berasosiasi signifikan $\left(\chi^{2}=1,735 ; \mathrm{p} .<.01\right)$ dengan status marital pengantin perempuan. (2) Mahar uang lebih lazim untuk janda. Sebaliknya, mahar perhiasan dan objek bersimbol agama sangat lazim untuk gadis tetapi tidak untuk janda. (3) Perbedaan jumlah mahar uang dan perhiasan untuk gadis dan janda ini sangat signifikan (p.<.01). (4) Nilai mahar uang untuk gadis jauh lebih besar (83\%) dibanding mahar janda. Namun mahar janda 'kembang' tetap saja ada yang selangit, mencapai \$2.314, jauh di atas rata-rata jumlah mahar uang standar untuk gadis. Satu hal yang menarik di sini bahwa besaran mahar perhiasan untuk janda $27 \%$ lebih berat dibanding mahar perhiasan untuk gadis.

Mahar diberikan kepada perempuan dengan pertimbangan status sosial keluarganya. Apakah praktek mahar berkorelasi signifikan dengan status sosial keluarga istri? Tren jenis mahar model ini terbukti bervariasi secara signifikan menurut status sosial istri, yaitu: (1) Mahar dalam wujud simbol praktis tradisional (uang dan properti) lebih dominan $(51 \%)$ diterapkan oleh warga kelas bawah. (2) Mahar dalam wujud simbol gaya penampilan (perhiasan) sebanyak 44\% dipraktekkan oleh warga kelas bawah. (3) Mahar dalam wujud simbol agama (peralatan shalat, Alquran, buku agama dan ritus keagamaan) lebih lazim dipraktekkan oleh masyarakat kelas menengah. Uji Chi kuadrat $\left(\chi^{2} 82,45\right.$; p.<.01) membuktikan asosiasi yang signifikan antara tren umum jenis mahar dengan status sosial istri. Alhasil, tren mahar sangat akrab dengan indeks status sosial keluarga perempuan. Temuan ini perlu secara tentatif diuji dari sudut pandang dan variabel sosial-ekonomi lainnya, terutama untuk melihat konsistensi pengaruh status sosial perempuan terhadap praktek mahar.

Secara transaksional, jenis dan besaran mahar adalah replikasi kesepakatan atau hasil negosiasi kedua belah pihak, suami dan istri, bahkan keluarga besar. Dalam konteks ini, jenis dan besaran tidak dapat dipisahkan dari tingkat kemampuan ekonomi laki-laki. Dengan kata lain, variasi jenis dan besaran mahar dapat dinegosiasi di banyak komunitas, seperti suku Banjar, Sasak, Bima dan Bugis. Jika jenis atau jumlah mahar tidak dapat disepakati, pertunangan seorang gadis bisa saja berbuntut putus dan pernikahan otomatis gagal. Studi ini membuktikan bahwa tren jenis mahar bervariasi signifikan menurut faktor status sosial suami. Walau signifikan $\left(\chi^{2}=11,34 ;\right.$ p. $\left.<.01\right)$, variasi jenis mahar tidak terlalu berkorelasi dengan status sosial suami dibanding status sosial istri. Ini artinya bahwa tren praktek jenis mahar tidak begitu akurat untuk dapat diprediksi berdasarkan variabel status sosial suami.

Apakah mahar berasosiasi dengan pendidikan suami dan istri?. Pertama, tren mahar bervariasi signifikan menurut tingkat pendidikan suami. Praktek mahar uang mengalami penurunan signifikan seiring dengan 
peningkatan pendidikan suami. Sebaliknya, intensitas praktek mahar perhiasan mengalami peningkatan seiring dengan peningkatan pendidikan suami. Variasi tren praktek jenis mahar tersebut berasosiasi signifikan dengan pendidikan suami. Data ini menunjukkan bahwa variabel tingkat pendidikan suami menjadi faktor determinan tren mahar. Misalnya suami dengan latar belakang pendidikan SD hampir bisa dipastikan (50\%) akan memberi mahar dalam wujud uang dan suami dengan latar belakang pendidikan tinggi hampir dapat dipastikan (66 \%) akan memberi mahar dalam wujud perhiasan.

Kedua, tren praktek jenis mahar juga berkorelasi signifikan $\left(\chi^{2}=198 ;\right.$ p. $\left.<.01\right)$ dengan variabel tingkat pendidikan istri. Bahkan trennya sangat mirip, jika tidak dapat dikatakan identik dengan tren praktek mahar menurut level pendidikan suami. Jika tingkat pendidikan bisa dijadikan satu indikator status sosial, data ini sebetulnya sudah dapat mengindikasikan temuan utama bahwa praktek mahar, dengan segala variasinya, erat kaitannya dengan status sosial seseorang di komunitas Muslim lintas daerah dan komunitas Muslim di nusantara.

Ketiga, perkawinan monogami di masyarakat Islam masih menjadi tipe ideal (93,3\%). Sebaliknya, poligami masih distigmatisasi, minimal dikelasduakan. Masyarakat umumnya belum terbuka menerima praktek poligami. Bahkan ada satu gejala bahwa poligami selalu dikaitkan dengan perkawinan penuh rahasia, (bodong, tanpa surat menyurat). Studi ini membuktikan bahwa tren jenis mahar berkaitan erat dengan model perkawinan (mono-poligami). Praktek mahar dalam wujud simbol tradisional lebih sering diterapkan pada perkawinan poligami. Sedangkan mahar simbol agama hampir dua kali lebih sering dipraktek pada perkawinan monogami. Ringkasnya, mahar dalam perkawinan poligami identik dengan objek yang bernilai nominal dan intrinsik secara ekonomi. Ini artinya bahwa poligami dan perkawinan janda erat kaitannya dengan faktor ekonomi. Apakah poligami bagi perempuan selalu bermotif ekonomi? Ini satu pertanyaan yang menarik untuk diteliti lebih lanjut.

Keempat, dalam tradisi sosial yang berpola eskriptifpewarisan, ${ }^{31}$ status sosial seorang anak sangat ditentukan oleh jalur keturunan, tepatnya status sosial orang tua,

${ }^{31}$ Ada dua pola konstruksi status sosial, yaitu model diwariskan (ascribed) dan dicapai (achieved). Model ascribed menekankan aspek siapa anda (turunan), bukan apa anda (capaian). Masyarakat tradisional menganut model pertama. Untuk model konstruksi status sosial, lihat Stark, Sociology, (Belmont, California: Wadsworth Publishing Company, 1989), h. 244-245; Theodorson dan Lucille Theodorson, Sociology: Principles and Applications, (St. Paul, MN, USA: West Publishing terutama ayah dalam hegemoni sistem kekerabatan patrilineal. Mayoritas masyarakat Muslim di tanah air sangat kental mempertahankan model pencitraan status sosial berbasis patrilinealisme. Studi ini membuktikan bahwa status sosial ayah istri berkorelasi signifikan $\left(\chi^{2}\right.$ 59,76; p.<.01) dengan tradisi praktek mahar. Praktek pernikahan masyarakat kelas bawah akrab dengan tren mahar bercorak objek tradisionalpraktis (uang/ perhiasan), sedangkan mahar dalam wujud simbol agama sangat akrab dengan masyarakat kelas atas.

Ringkasnya, hipotesis pertama (tren praktek mahar berasosiasi signifikan dengan status sosial) tidak dapat terbantahkan. Namun tren fenomena kualitatif ini perlu diuji silang dengan data kuantitatif. Apakah besaran mahar dalam wujud uang dan perhiasan bervariasi signifikan menurut status sosial dan tingkat pendidikan suami dan istri?. Bagian berikut akan menguji secara spesifik pengaruh sub-variabel status sosial suami dan istri terhadap variasi besaran mahar. Untuk tujuan tersebut, uji bivariate one way of anova akan dilakukan.

Tabel 1 : Uji ANOVA Jumlah Mahar Uang (Dollar) dan Perhiasan

Menurut Pendidikan dan Status Sosial Suami-Istri dan Orang tua Istri

\begin{tabular}{|c|c|c|c|c|c|}
\hline \multicolumn{3}{|c|}{ A. MAHAR UANG } & \multicolumn{3}{|c|}{ B. MAHAR PERHIASAN } \\
\hline Status Sosial & $\mathbf{F}$ & Sig. & Status Sosial & $\mathbf{F}$ & Sig. \\
\hline 1. Pendidikan Suami & 0,34 & TS & $\begin{array}{l}\text { 1. Pendidikan } \\
\text { Suami }\end{array}$ & 23,311 & p. $<.01$ \\
\hline $\begin{array}{l}\text { 2. Status Sosial } \\
\text { Suami }\end{array}$ & 12,19 & p. $<.01$ & $\begin{array}{l}\text { 2. Status Sosial } \\
\text { Suami }\end{array}$ & 16,436 & p. $<.01$ \\
\hline 3. Pendidikan Istri & 2,07 & TS & 3. Pendidikan Istri & 18,491 & p. $<.01$ \\
\hline 4. Status Sosial Istri & 19,87 & p. $<.01$ & $\begin{array}{l}\text { 4. Status Sosial } \\
\text { Istri }\end{array}$ & 8,674 & p. $<.01$ \\
\hline \multirow{2}{*}{\multicolumn{3}{|c|}{ Catatan $:$ TS $=$ tidak signifikan }} & $\begin{array}{l}\text { 5. Pendidikan } \\
\text { Ayah Istri } \\
\end{array}$ & 0,976 & TS \\
\hline & & & $\begin{array}{l}\text { 6. Status Sosial } \\
\text { Ayah Istri }\end{array}$ & 9,953 & p. $<.01$ \\
\hline
\end{tabular}

Tabel 1 (Bagian A) menyajikan informasi hasil uji Anova tentang variasi praktek jumlah mahar uang dan perhiasan menurut pendidikan, status sosial suami serta status sosial orang tua istri sebagai berikut: (1) Satu fakta yang menarik bahwa level pendidikan suami dan istri tidak terkait langsung secara signifikan dengan variasi jumlah mahar uang. Ini artinya bahwa praktek mahar uang tidak dipengaruhi oleh variabel pendidikan suami atau istri. (2) Variabel jumlah mahar uang bervariasi secara signifikan menurut status sosial suami dan istri. Dengan kata lain, jumlah mahar uang tidak terbukti berkorelasi signifikan dengan tingkat pendidikan.

Apakah tren yang sama juga terbukti dalam kasus jumlah mahar perhiasan? Hasil uji statistik (Bagian B)

Company, 1990), h. 189-191; Wright II, et.als, Perspective: An Introduction to Sociology, (Hinsdale, Illinois: The Dryden Press, 1975), h. 187-245. 
menunjukkan realitas yang berbeda dengan data tentang korelasi jumlah mahar uang dengan pekerjaan dan tingkat pendidikan suami dan istri. Di sini jumlah mahar perhiasan bervariasi signifikan menurut tingkat pendidikan suami dan istri serta status sosial ayah istri. Tetapi ia tidak bervariasi secara signifikan dengan pendidikan ayah istri. Dengan kata lain, tren praktek jumlah mahar uang dan perhiasan berbeda dalam hal variabel penjelas. Jumlah mahar perhiasan dapat dijelaskan dengan pendidikan suami dan istri serta status sosial ayah istri. Sedangkan jumlah mahar uang tidak akurat diprediksi dengan variabel pendidikan suami dan istri serta status sosial ayah istri.

Terakhir, apakah variabel status sosial suami, istri dan ayah istri berkorelasi signifikan dengan jumlah mahar perhiasan?. Semua variabel status sosial terbukti berkorelasi signifikan dengan besaran jumlah mahar perhiasan. Oleh sebab itu, pertanyaan "Kenapa besaran jumlah mahar uang tidak bervariasi secara signifikan menurut variabel tingkat pendidikan" adalah isu yang harus dikritisi secara khusus pada bagian analisis dan interpretasi berikut ini.

\section{Interpretasi dan Refleksi}

Berdasarkan temuan di atas maka perlu dianalisis lebih kritis kenapa dan bagaimana mekanisme variabel sosial dan kultural mempengaruhi corak praktek mahar di masyarakat Muslim. Pertama, tren tradisi praktek mahar mengalami perubahan yang signifikan seiring perjalanan waktu. Teori modernisasi menegaskan bahwa masyarakat mengalami perubahan linear, dari komunitas sederhana yang identik dengan kelas bawah dan bercirikan kehidupan tradisional-agraris, ke masyarakat industri-teknologi yang cenderung mengapresiasi nilainilai simbolik dalam kehidupan, baik simbol penampilan aksesoris (perhiasan) atau simbol keagamaan. Masyarakat Muslim Indonesia di tahun 1970-an masih sangat tradisional dan terus bergumul dengan usaha pemenuhan hajat ekonomi di tarap awal sejahtera. Di penghujung abad XX dan di awal abad XXI taraf hidup masyarakat mengalami peningkatan signifikan yang diikuti dengan perubahan gaya dan orientasi pemaknaan hidup. Dalam konteks peningkatan ini, orang mulai mengejar target ritme hidup non material. Gaya hidup glamour mulai menjadi ciri baru masyarakat yang sedang berkembang. Orang kaya baru tanpa malu bahkan bangga pamer gaya hidup mereka yang sering berpenampilan berlebihan.

Secara subtantif, budaya penampilan telah menjebak orang dalam kesadaran formalistik, sebatas indah di level kulit namun hampa dan menipu di ranah batin. Banyak fakta menguatkan bahwa budaya material dan penampilan telah menggiring orang pada perasaan kehampaan makna hidup. Rumah tangga dengan warna simbol material dan penampilan telah mengikis nilainilai suci dan luhur pernikahan, yaitu nilai spiritual. Akibatnya, dalam kehampaan batin banyak orang berusaha menengok kembali signifikansi muatan nilainilai religius dalam pernikahan. Bagi kelompok baru ini, inisiatif dan awal proses pernikahan harus dibingkai, dimaknai dan diboboti dengan nilai-nilai luhur. Dalam kesadaran ini, penggunaan simbol keagamaan menjadi satu pilihan dalam penentuan jenis mahar karena ia dirasakan mampu meraih ulang nilai-nilai luhur yang sempat terlupakan dalam pernikahan. Atas dasar alasan ini, penggunaan objek bersimbol agama sebagai mahar menjadi pilihan yang tepat.

Gejala penggunaan simbol agama untuk mahar juga tidak bisa dipisahkan dari tren global religious resurgence hampir di setiap belahan dunia, pasca keruntuhan hegemoni materialisme-hedonistik terutama pada masyarakat kelas menengah baru yang dicirikan dengan tingkat pendidikan yang tinggi. Kelahiran kembali spirit religius ini membisikkan kerinduan terhadap sentuhan religius. Dalam bingkai kesadaran ini, masyarakat perkotaan semakin lebih sering menggunakan mahar dalam bentuk objek simbol agama dan perhiasan. Bahkan belakangan ada kelompok sosial tertentu menjadikan paket umroh dan haji sebagai mahar. Lebih dari itu, ada orang kaya yang melaksanakan akad pernikahan di tanah suci, di bawah naungan Ka'bah, di sela-sela mereka melaksanakan ibadah umroh.

Kedua, tradisi mahar juga erat kaitannya dengan daerah tertentu. Mahar uang menjadi tradisi yang kuat di Kalimantan Selatan. Mahar berbentuk objek simbol agama dominan di Sumatera Barat. Di daerah yang bercirikan kota metropolitan, seperti DKI Jakarta, mahar perhiasan dan simbol keagamaan belakangan menjadi semakin lazim. Variasi tren tradisi mahar menurut daerah ini tidak dapat dipisahkan dari cara lokal memaknai pernikahan. Masyarakat Banjar masih cenderung menjadikan jumlah mahar sebagai indeks status sosial. Dalam konteks ini ada perasaan malu jika anggota keluarga menikah dengan mahar yang murah. Bahkan ada keluarga perempuan lebih memilih membatalkan lamaran daripada berniat mengurangi jumlah mahar. Mahar yang rendah bisa dinilai merendahkan martabat keluarga perempuan. Dalam kasus seperti ini ada sindiran sinis dari keluarga perempuan bahwa "harga sapi dan kerbau saja lebih mahal dibanding jumlah mahar yang diberikan”. Dengan kata lain, di saat masyarakat Banjar tetap cenderung menilai mahar sebagai indeks nobilitas keluarga besar, mahar yang tinggi akan selalu tetap dibanggakan. Akibatnya, mahar yang mahal akan tetap 
menjadi icon model praktek mahar di masyarakat asli Banjar.

Berbeda dengan Muslim Banjar, Muslim Minang di Sumatera Barat nampaknya tidak terbiasa mengaitkan mahar dengan status sosial keluarga perempuan. Mereka lebih melihat mahar sebagai proses pembentukan keluarga baru yang memerlukan modal awal. Dari sudut pandang ini, mahar yang tinggi dapat menyulitkan calon pengantin laki-laki. Akibatnya banyak orang beranggapan bahwa mahar yang tinggi tidak lebih penting dibanding dengan modal biaya rumah tangga baru. Selain itu, Muslim Sumatera Barat ,khususnya Padang Pariaman, masih menganut asas dualisme hukum yang membedakan antara mahar (dower) dan maskawin (dowry). Mengacu pada fikih, tradisi Minang tetap mewajibkan mahar yang harus diberikan pengantin laki-laki. Namun tradisi bajapuik di Pariaman (nikah jemputan) juga mewajibkan keluarga perempuan untuk membayar sejumlah uang jemputan pada keluarga laki-laki, sejenis konpensasi. ${ }^{32}$ Dualisme norma mahar dalam tradisi bajapuik ini mengisyaratkan bahwa pranata mahar lebih dimaknai sebatas syarat formal pernikahan. Di sini mahar tidak lazim dikaitkan dengan status sosial keluarga perempuan. Akibatnya, mahar material-uang tidak dibanggakan dalam kaitannya dengan kehormatan keluarga. Di sini mahar bahkan dapat dimaknai secara sederhana dan lebih bermakna simbolik daripada pemaknaan hakikinya.

Ketiga, praktek mahar erat kaitannya dengan kelas atau status sosial seseorang (baik pengantin laki-laki atau perempuan). Dalam hal ini tradisi mahar dalam wujud uang identik dengan kultur masyarakat kelas bawah. Mereka umumnya menekuni pekerjaan tradisional, sebagai petani, pelaut, nelayan, buruh, pekerja domestik, sopir, masinis, mandor, tukang ojek, tukang becak, penjahit, tukang cukur, karyawan rendahan, tenaga keamanan dan kebersihan, pesuruh kantor, pelayan warung/toko, tukang kebun, penjual makanan keliling, kondektur dan kenek.

Pola praktek mahar uang ini secara teoritis dapat dipahami dari perspektif ekonomi. Kecenderungan masyarakat kelas bawah untuk memilih uang sebagai mahar harus dipahami dengan logika praktis pemenuhan kebutuhan dasar. Kehidupan kelas bawah relatif sederhana dan masih terbatas pada pemenuhan kebutuhan dasar. Dalam konteks ini uang menjadi media yang sangat praktis untuk segala kebutuhan. Intinya, harapan masyarakat kelas bawah umumnya masih relatif sederhana yang tergambar dari tradisi praktis

\footnotetext{
${ }^{32}$ Azwar, Matrilokal dan Status Perempuan dalam Tradisi Bajapuik, (Yogyakarta: Galang Press, 2001), h. 69-97.
}

di atas. Dengan dinamika hidup dan kebutuhan yang serba nyata dan sederhana, setiap sesuatu, termasuk mahar, akan lebih dimaknai secara eksposisif, praktis dan apa adanya, tanpa pemaknaan simbolik ideologis yang lebih bernuansa gaya hidup glamour.

Bagi masyarakat kelas bawah, persoalan utama adalah pemenuhan kebutuhan dasar yang diatasi secara praktis dan instan dengan uang. Sejauh ini uang dianggap dapat dijadikan alat tukar secara cepat dan ringkas guna memenuhi kebutuhan dasar. Uang memiliki nilai praktis yang sangat tinggi jika dibandingkan dengan perhiasan, apalagi perangkat alat shalat dan Alquran yang tidak bernilai ekonomi. Ini artinya bahwa untuk menjadikan perhiasan sebagai alat tukar transaksi, pemilik perhiasan harus terlebih dahulu menjualnya. Dari sisi ini perhiasan kurang memiliki nilai praktis dan objek simbol agama tidak bernilai ekonomi. Akibatnya, di masyarakat yang kuat mempertahankan budaya material praktis, uang tetap menjadi pilihan utama untuk mahar dan uang sulit dapat dikonpensasi dengan objek-objek yang hanya bersimbol penampilan. Tafsiran ini sejalan dengan hegemoni tradisi dan kultur uang sebagai indikator status sosial di banyak masyarakat Muslim tanah air.

Keempat, praktek besaran mahar, terutama perhiasan, selalu identik dengan variabel status sosial pengantin laki-laki dan perempuan serta ayahnya. Realitas ini harus dipahami dari kultur dan struktur sosial mayoritas Muslim Indonesia. Sudah menjadi bagian dari tradisi komunitas, misalnya Aceh, Banjar, Sasak, Bima, Bugis dan Arab, terutama bahwa walaupun jumlah mahar dapat dinegosiasikan antara keluarga calon pengantin laki-laki dan perempuan, namun keluarga perempuan faktanya adalah sebagai pihak yang sangat menentukan bentuk dan besaran mahar. Pada kasus ekstrim, proses pernikahan tidak jarang terpaksa dibatalkan hanya karena tidak tercapai kesepakatan besaran mahar pada tahapan proses negosiasi mahar setelah lamaran diterima. Namun belakangan, terutama di masyarakat perkotaan yang kuat menjaga citra kehormatan keluarga, orang tua cenderung tidak lagi menekankan unsur besaran mahar. Semuanya lebih diserahkan kepada anak-anak. Cerita pertunangan yang putus hanya karena tidak tercapai kesepakatan harga mahar sudah jarang terdengar. Namun karena mahar masih dinilai sebagai citra kehormatan keluarga, masalah ini tetap krusial dalam perencanaan pernikahan di banyak masyarakat Islam.

Orang dapat saja memaknai nilai sosial mahar secara beragam. Namun dapat disepakati bahwa pada masyarakat yang kuat memaknai mahar sebagai citra nobilitas keluarga, besaran mahar merupakan satu indeks penting ekspresi status sosial. Tampilan 
wajah atau pendidikan boleh saja 'pas-pasan' menurut standar umum, tetapi jika seorang perempuan berasal dari keluarga terhormat maka jumlah maharnya bisa dipastikan cukup besar atau mewah. Besaran mahar ini dapat dipahami dari nilai simbolik dan praktisnya. Secara praktis, mahar sering dijadikan kapital awal bagi pasangan baru untuk menyiapkan kebutuhan berumah tangga. Secara sosial, mahar di banyak masyarakat Muslim sering digunakan untuk membeli kebutuhan perangkat tempat tidur, pakaian, perlengkapan lain dan persiapan resepsi perkawinan. Semakin besar jumlah mahar tentu semakin leluasa pengantin perempuan dan keluarganya untuk membeli kebutuhan perayaan pernikahan. Saat dekorasi rumah atau kamar pengantin dan aura perhelatan walimmah al-urs sering dijadikan ajang pamer gengsi, prestise seorang perempuan, terutama keluarganya, kesadaran ideologis kelas sosial ini akan selalu memotivasi seseorang untuk mendapatkan jumlah mahar yang besar untuk memuaskan hasrat pamernya.

Selain itu perlu dicatat bahwa warga masyarakat tertentu, terutama mereka yang masih menilai mahar sebagai indeks status sosial, sudah terbiasa membicarakan nilai atau harga mahar pengantin yang dirayakan. Besaran mahar sering menjadi bahan laris obrolan undangan. Dalam konteks ini tidak jarang ada saja orang yang mencibir atau mencemooh keluarga yang menentukan harga mahar terlalu rendah. Mahar yang tinggi memang tidak salah, tetapi mahar sederhana, dalam Islam, lebih ditekankan secara fikih. Namun tradisi lokal sering membelokkan prinsip dasar mahar. Jika awalnya mahar difungsikan sebagai wujud ekspresi kasih sayang, ketulusan, keseriusan dan segala hal-hal yang positif secara moral untuk keperluan perempuan, praktek mahar di banyak masyarakat Islam sering mengabaikan anasir nilai-nilai moral tersebut. Di sini fikih tradisional yang didasarkan pada kaidah al-âdah muhakkamah ikut melegitimasi konstruksi mahar tradisional ini. Misalnya dalam fikih dikenal dengan mahr mitsl (mahar semisal) dimana mahar diharapkan sesuai dengan standar kebiasaan lokal mengenai jenis atau besaran mahar. Pemaknaan mahar secara ekonomi dan formalistik ini tentu mereduksi kedalaman konsep mahar dalam Islam.

Ada hal lain yang harus diperhatikan dari studi ini yaitu perbedaan konsep ideal mahar Islam dengan prakteknya di masyarakat Muslim. Fakta di banyak komunitas, pemaknaan mahar lebih menekankan aspek sosial (dimensi profan) ketimbang unsur moral agama. Karenanya, semakin kesadaran akan nilai status sosial terus menghantui spirit kebanggaan seseorang, maka dorongan untuk menginginkan (memberi/menerima) jumlah mahar yang banyak atau tinggi akan terus hidup di masyarakat. Merujuk hasil studi ini, mahar dalam tradisi Muslim Banjar dan beberapa masyarakat lainnya seperti Sasak, Bugis, Mandar dan Arab, masih terus akan lebih dimaknai sebagai indeks status sosial ketimbang penegasan unsur moral dan spiritualnya, walaupun skala penekanan prioritas makna mahar seperti ini sudah relatif mencair.

Kelima, secara sosiologis, intervensi orang tua sulit dihindarkan untuk dijadikan bahan pertimbangan bagi seorang anak, terutama anak gadis, saat menentukan jenis dan jumlah mahar pernikahannya. Ini artinya bahwa penelitian sosiologis tentang praktek mahar harus mengaitkannya dengan status sosial keluarga perempuan. Ini krusial karena faktor tersebut secara statistik sangat menentukan corak perwajahan praktek mahar di masyarakat, sebagaimana juga ditemukan Korson dalam penelitiannya di komunitas Muslim Pakistan.

Ada perbedaan yang menarik antara hasil studi ini dengan hasil penelitian di sejumlah negara anak benua Asia Selatan. Jika mahar dalam wujud maskawin sangat tinggi (selangit, excessive, mematikan) di Asia Selatan, hasil penelitian ini tidak menemukan fenomena yang serupa di tanah air. Jumlah maksimal mahar uang relatif tidak terlalu tinggi (\$2.565) dan masih di kisaran standar umum. Faktanya, jika terlalu tinggi, calon pengantin laki-laki tidak jarang tidak akan memaksakan diri untuk tetap menikahi perempuan pilihannya. Romantisisme dan keterbukaan orang tua terhadap perubahan menjadi faktor penting dalam konstruksi tren jumlah mahar di tanah air. Ini menjadi satu perbedaan tren mahar di tanah air dibanding tren yang mapan dan lestari di Pakistan dan India. Secara umum, karena prinsip ideologis, besaran maskawin dan juga mahar di anak benua Asia Selatan sulit dinegosiasi. Dan sebaliknya praktek mahar di tanah air lebih lentur sebagai hasil negosiasi. Walaupun pada komunitas tertentu, banyak keluarga yang arogan dan secara sepihak menetapkan jenis dan besaran mahar, akhirakhir ini keluarga dan kedua pengantin begitu terbuka memaknai mahar. Sikap terbuka seperti ini menjadi faktor utama untuk menjelaskan tren perubahan mahar lintas waktu terutama akhir-akhir ini pada kalangan generasi kelas menengah baru di tanah air.

Keenam, perkembangan tren penggunaan mahar objek bersimbol agama merupakan fakta yang menarik di tanah air walaupun kasus seperti ini pernah terjadi di era Rasulullah Saw. Namun hal yang menarik adalah frekuensi dan intensitas tren pergeserannya dari uang dan objek lain yang bernilai praktis ke arah penggunaan simbol-simbol agama. Belakangan simbol agama semakin diminati untuk mahar. Gejala ini terlihat dari peta 
global dalam hal polarisasi keberagamaan di masyarakat. Banyak bukti yang menunjukkan kesemarakan aktivitas keagamaan di kalangan generasi muda. Dalam setting ini orang menjadi terdorong menggunakan simbol-simbol agama sebagai mahar. Logikanya sederhana. Seiring dengan kemunculan ulang kesadaran peran agama dalam hidup seseorang maka pemberian mahar yang bersimbol agama di awal perkawinan (momentum yang bersejarah karena pengantin disebut raja sehari) diharapkan dapat menyadarkan kedua mempelai untuk selalu hidup rukun dan damai dalam naungan payung ilahiah yang tersimbolisasi via instrumen alat shalat dan kitab suci.

Ketujuh, kenapa besaran mahar sangat terkait dengan status marital perempuan?. Dalam hal ini, besaran mahar janda secara statistik jauh lebih kecil dibanding dengan mahar gadis walaupun besaran mahar perhiasan janda secara umum di atas rata-rata mahar perhiasan gadis. Hal ini dapat dijelaskan dari sistem sosial dan budaya patriarki. MasyarakatIndonesiasangat patriarkis dan tidak memberi ruang kebebasan yang besar kepada perempuan untuk menentukan pilihan dalam kehidupannya terutama janda. Ruang gerak janda sangat terbatas. Stereotip dan stigmatisasi sosial serta kultural selalu mengintai setiap pergerakan janda. Label buruk lumrah disematkan kepada janda yang lincah atau gesit. Ada istilah janda genit untuk menunjuk janda yang mobile dan progresif. Secara kultural, masyarakat belum dapat menerima dengan baik jika ada perempuan, terutama janda, yang kasak-kusuk berinisiatif mencari pasangan hidupnya. Akibatnya posisi tawar janda sangat lemah di pasar jodoh. Janda dipaksa oleh kultur, keadaan dan sistem sosial untuk terus menunggu jodohnya, bahkan terkadang dengan segala kepasrahan harus menerima lamaran lakilaki yang sudah beristri. Nasib tragis perempuan tidak berhenti sampai di sini. Secara tradisional, perempuan sering tidak dilibatkan dalam proses negosiasi penentuan mahar dan inisiasi perkawinan. Di sini keluarga adalah pihak yang paling berperan. Karena sering didera rasa malu, pihak keluarga lazim mendorong anak jandanya untuk cepat menikah walaupun dengan mahar yang rendah atau menikah secara bodong.

Status janda sering distigmatisasi sebagai akar kegagalan perrnikahan. Dalam konteks ini masyarakat masih cenderung menghujat perempuan untuk setiap ada kasus perceraian terlepas apapun faktor pemicunya. Stereotipe ini menyudutkan janda pada posisi yang sulit di pasar jodoh dan negosiasi mahar. Akibatnya kepasrahan sulit terelakan dalam kehidupan perempuan saat menentukan jodoh dengan status jandanya. Kelakar pejoratif masih sering terdengar bahwa "kalau ada laki-laki -walaupun tua renta- yang mau menikahi janda maka itu sudah untung". Stigmatisasi status janda tergambar pada cara masyarakat Muslim merayakan resepsi pernikahan janda. Perayaan pernikahan janda dilakukan sangat sederhana dengan persiapan seadanya atau tanpa perayaan. Keadaan sulit ini nampaknya menjadi penyebab utama kenapa banyak janda merelakan jodohnya jatuh ke tangan laki-laki yang sudah beristri seperti terlihat pada studi ini. Banyak janda terpaksa menerima nasib sebagai 'madu' yang harus rela dengan cap merebut suami orang. Dengan posisi tawar ini perempuan sulit menetapkan standar ideal untuk memenuhi kebutuhan pernikahannya. Faktor ideologis ini nampaknya bisa menjelaskan kenapa mahar janda jauh lebih murah ketimbang mahar gadis.

\section{Penutup}

Dalam ilmu fisika dijelaskan bahwa bentuk benda cair, seperti air, dipolakan berdasarkan wadah yang menampungnya terutama saat dipadatkan. Bahkan juga dalam hal penampakan warnanya. Misalnya air yang sesungguhnya bening nampak berwarna biru saat ia ditampung di gelas biru. Bentuk es akan mengikuti pola pembungkus atau tempatnya. Adonan kue akan dipola baku sesuai dengan bentuk loyang cetakannya seperti beragam bentuk biskuit yang lucu dan disukai anakanak.

Hukum di ranah nilai-nilai moral seperti benda cair. Ia lentur, fleksibel dan mengalir mengikuti arus dan ritme format lokal. Secara sosiologis, struktur sosial dan budaya menjadi faktor penting dalam konstruksi atau formalisasi hukum terutama di level institusionalisasi. Seorang antropolog hukum, Bohanan, menegaskan bahwa hukum positif adalah replikasi aturan yang hidup (living law) di masyarakat. Saat suatu hukum asing diadopsi oleh regim baru maka ia akan selalu dimaknai dan dikonstruksi sesuai dengan cetak biru norma tradisi lokal. Di sini tidak ada hukum asing yang sungguh original sesuai standar lamanya tanpa ia dipola menurut sentuhan citra dan format lokal yang baru.

Pranata mahar adalah satu instrumen hukum yang original Islam. Ia memiliki genre yang khas Islam di basis nilai-nilai moral. Namun sebagai bentuk pemberian kompensasional mahar bukan sebuah norma yang asing bagi masyarakat asli Indonesia. Institusi pernikahan di nusantara sebelum Islam datang sudah lama mengenal norma pemberian pra marital. Setiap adat lokal memiliki aturan tentang syarat kesahihan pernikahan. Salah satunya adalah aturan tentang pemberian yang harus diserahkan ke pihak yang dinilai dirugikan sebagai akibat perkawinan. Jenis objek yang diberikan sangat beragam. Di sini pemberian dianggap sebagai satu upaya 
pemulihan (restitusi) kerugian yang dialami pihak tertentu. Misalnya karena pengantin laki-laki akan menjadi aset atau instrumen ekonomi keluarga perempuan di ranah Padang Pariaman, perkawinan ala bajapuik tetap eksis dan terus ditaati oleh Muslim Minang walaupun fikih tidak mengenal tradisi mahar ala bajapuik. Alhasil, hukum baru saat diadopsi oleh satu masyarakat ia akan selalu diformat baku dalam bingkai normatif lokal.

Refleksi teoritis ini sejalan dengan sinyalemen Ibn Qayyim yang dikutip di awal tulisan. Lalu apakah eksistensi hukum Islam, seperti kasus mahar, harus distandarisasi sesuai kerangka formalitas norma lokal?. Jika demikian, kita sulit menolak teori resepsi ala ilmuan Belanda yang menegaskan bahwa hukum Islam akan menjadi hukum positif di tanah air ketika ia telah diterima atau tidak bertentangan dengan norma adat setempat. Hazairin menilai pendapat ini sebagai sebuah teori konspirasi iblis karena ia dinilai mempecundangi hukum Islam. Menurutnya, keberadaan hukum Islam di atas hegemoni hukum adat atau dengan kata lain eksistensi hukum Islam di ranah lokal-praktekal tidak harus terlebih dahulu diterima adat. Hukum Islam tetap sebagai hukum positif di satu komunitas adat walaupun ia bertentangan dengan standar adat.

Hazairin nampaknya mengingkari fakta bahwa banyak hukum Islam yang memakai format lokal walaupun ia tidak kehilangan spirit moralnya. Secara sosiologis, tidak salah jika hukum Islam dibingkai sesuai format lokal. Formalisasi hukum Islam seperti mahar sebagai contoh nyata. Apakah teoritisasi ini mendistorsi dan mereduksi universalitas hukum Islam?, Apakah hukum Islam bersifat lokal?. Mengacu pada gagasan Ibn Qayyim, nilai-nilai moral hukum Islam, menurut hemat penulis, tetap universal, hanya struktur formalnya yang bercorak lokal. Akhirnya wacana sosiologi-antropologi hukum mampu menjelaskan variasi tren praktek hukum mahar di tanah air sesuai dengan faktor struktur sosial dimana pranata mahar diterapkan. Dari sisi ini adalah benar bahwa hukum, menurut seorang mantan hakim agung Amerika Serikat, bukan satu kompilasi konstruk logis yang ahistoris-asosiologis, tetapi ia adalah refleksi rangkaian pengalaman yang menyejarah. Hukum adalah hasil pergumulan banyak kekuatan sosial, kultural, politik, juga agama.

Ringkasnya, setiap hukum selalu memiliki dimensi lokalitasnya walaupun ia diadopsi dari genre tradisi dan sistem yang sangat berbeda dengan konteks barunya. Llewellyn dengan mengikuti logika mazhab sejarah ala rintisan Von Savigny lebih jauh menegaskan bahwa hukum adalah suatu bagian integral dari kebudayaan. Akibatnya analisis kritis terhadap hukum tidak boleh menyerabutnya dari anasir diskursif dan konstruktif lokalnya. Dalam hal ini, secara sosiologis, relasi antara hukum dan masyarakat seperti dua sisi mata uang yang keberadaan makna salah satu sisinya sangat ditentukan oleh nilai sisi yang lain. Hukum adalah cerminan struktur sosial. []

\section{Pustaka Acuan}

Afzal, Sarwat dan Imtiaz Subhani, To Estimate an Equation Explaining the Determinants of Dowry, Iqra University, 2009.

Aini, Noryamin, "Mahar dalam Konteks Sosial-Budaya Muslim; Mahar dan Status Sosial dalam Kehidupan Masyarakat Amuntai, Kalimantan-Selatan," dalam Khazanah: Majalah Ilmiah Keagamaan dan Kemasyarakatan, Vol.1 (6), (2002).

Amin, Sajeda, dan Mead Cain. "The Rise of Dowry in Bangladesh" dalam The Continuing Demographic Transition, Gavin W. Jones, et.als.,eds., Oxford: Oxford University Press, 1997.

Anderson, Siwan, "The Economics of Dowry and Brideprice," dalam Journal of Economic Perspectives, Vol. 21 (4) (2007).

------.---, "Why Dowry Payments Declined with Modernization in Europe but Are Rising in India," dalam Journal of Political Economy, Vol. 111 (2), (2003).

---------, Dowry and Property Rights, Department of Economics, University of British Columbia, Canada, (August 2004).

Arunachalam, Raj dan Trevon D. Logan, "On the Heterogeneity of Dowry Motives." National Bureau of Economic Research, Working Paper 12630, (2006).

Azwar, Welhendri, Matrilokal dan Status Perempuan dalam Tradisi Bajapuik, Yogyakarta: Galang Press, 2001.

Bambawale, U. dan A. Ramanama, "Mate Selection in Inter-Religious Marriages: An Indian Perspective", dalam Indian Journal of Social Work, Vol. 42, (2) (1981).

Blenkhorn, Lindsey E., "Notes: Islamic Marriage Contracts in American Courts: Interpreting Mahr Agreements as Prenuptials and Their Effect on Muslim Women," dalam Southern California Law Review, Vol. 76 (2002).

Bloch, F. dan Vijayendra Rao. "Terror as a Bargaining Instrument: A case Study of Dowry Violence in Rural India," dalam The American Economic Review, Vol. 92 (4), (2002).

Bumiller, E.F., May You Be the Mother of A Hundred Sons, New Delhi: Penguin, 1992. 
Carolina, Ifeka, "Hierarchical Women: The 'Dowry' System and Its Implications among Christians in Goa," dalam Contributions to Indian Sociology, Vol. 23 (2) (1989).

Chowdhury, Farah D., "Dowry, Women, and Law in Bangladesh," dalam International Journal of Law and Policy Family, Vol. 24 (2), (2010).

Crone, Patricia dan Martin Hinds, God's Caliph: Religious Authority in the First Centuries of Islam, Cambridge: Cambridge Univesity Press, 1986.

Dalmia, Sonia dan Pareena G. Lawrence, "The Institution of Dowry in India: Why It Continues to Prevail," dalam Journal of Developing Areas, Vol. 38 (2).

Dutton, Yasin, Asal Mula Hukum Islam: Alqur'an, Muwatta', dan Praktik Madinah, diterjemahkan oleh M.Maufur, Jogjakarta: Islamika, 2003.

El Fadl, Khaled M. Abou, Atas Nama Tuhan: Dari Fikih Otoriter ke Fikih Otoritatif, diterjemahkan oleh R. Cecep Lukman Yasin, Jakarta: Serambi, 2004.

Esteve-Volart, Berta, 2004. "Dowry in Rural Bangladesh: Participation as Insurance against Divorce" (diunduh dari http://dept.econ.yorku.ca/\%7Eberta/dowry_ web.pdf).

Fournier, Pascale, "Flirting with God in Western Secular Courts: Mahr in the West," dalam International Journal of Law, Policy and the Family," Vol. (2009).

Freeland, Richard, "The Islamic Institution of Mahr and American Law," dalam Gonzaga Journal of International Law, Vol. 4 (I) (2000-01).

Geertz, Hildred, The Javanese Family: A Study of Kindship and Socialization, New York: The Free Press of Glencoe, 1961.

Gray, Robert F. "Sonjo Brideprice and the Question of African "Wife Purchase," dalam American Anthropologist, Vol. 62 (1), (1960).

Greenberg, Judith G. "Criminalizing Dorwy Deaths; The Indian Experience," dalam Journal of Gender, Social Policy and the Law, Vol. 11 (2) (2003).

Grusky, David B., Social Stratification: Class, Race, and Gender in Sociological Perspective, Boulder, Colorado: Westview Press Inc., 1994.

Gupta, Nidhi, "Women's Human Rights and the Practice of Dowry in India; Adapting A Global Discourse to Local Demands," dalam Journal of Legal Pluralism, Vol. 48, (2003).

Guzzetti, L., "Dowries in Fourteenth-Century Venice," dalam Renaissance Studies, Vol. 16 (4), (2002).

Haderiva, Kajian terhadap Pemberian Mahar yang Tinggi pada Masyarakat Adat Bugis di Kota Sebatik; Ditinjau dari Hukum Islam (Studi Kasus di Kecamatan Sebatik, Kabupaten Nunukan, Kalimantan Timur), Skripsi, Malang: Universitas Muhammadiyah, 2006.

Hammudah, 'Abd al-Ati, The Family Structure in Islam, Indianapolis: American Trust Publication, 1977.

Heyer, J. “The Role of Dowries and Daughters' Marriages in the Accumulation and Distribution of Capital in a South Indian Community," dalam Journal of International Development, Vol. 4 (4), (1992).

Huq, Lopita dan Sajeda Amin, "Dowry Negotiations and the Process of Union Formation in Bangladesh: Implications of Rising Education," Unpublished Manuscript, 2001.

Jawziyyah, al-, Ibn Qayyim, Syams al-Dîn Abî 'Abd Allâh Muhammad ibn Abî Bakr, I lâm al-Muwaqqi în 'an Rabb al-'Alâmin, Kairo: Muthâba'ah al-Islâm, 1980.

Korson, H.J. "Dower and Social Class in an Urban Muslim Community," dalam Journal of Marriage and the Family, Vol. 29, (3) (1967).

--.-----, "The Roles of Dower and Dowry as Indicators of Social Change in Pakistan," dalam Journal of Marriage and the Family, Vol. 30 (4), (1968).

Kressel,G.M, "Brideprice Reconsidered," dalam Current Anthropology, Vol. 18 (3), (1977).

Kumari,R, Brides are Not for Burning. Dowry Victims in India. Radiant Publishers, 1989.

Lambiri-Dimaki, J. "Dowry in Modern Greece: An Institution at the Crossroads between Persistence and Decline" dalam The Marriage Bargain: Women and Dowries in European History, Marion A. Kaplan, ed., New York: Havorth Press, 1985.

Levy, Reuben, The Social Structure of Islam, Cambridge: The University Press, 1962.

Martin, D., "A Comment on Whether American Women Do Marry Up," dalam American Journal of Sociology, Vol. 35, (1972), h. 237.

Mehdi, Rubya, "Danish Law and the Practice of Mahr among Muslim Pakistanis in Denmark" dalam International Journal of the Sociology of Law, Vol. 31 (2003).

Moors, Annelies, "Women and Dower Property in Twentieth-Century Palestine: The Case of Jabal Nablus," dalam Islamic law and Society, Vol. 1 (3), (1994).

Nishimura, Y., "Marriage Payments among the Nagarattars in South India," dalam Contributions to Indian Sociology, Vol. 28 (3), (1994).

Oldenburg, Veena, "Dowry Murders in India: A Preliminary Examination of the Historical 
Evidence," dalam Women's Lives and Public Policy: The International Experience, Meredith Turshen and Briavel Holcomb, eds, Westport, CT: Greenwood Press, 1993.

Oman, Nathan B. "Bargaining in the Shadow of God's Law: Islamic Mahr Contracts and the Perils of Legal Specialization," William \& Mary Law School Research Paper, No. 09-46 (diunduh dari http://ssrn.com/ abstract $=1586433)$.

Papps, Ivy, "The Role and Determinants of BridePrice: The Case of a Palestinian Village," Current Anthropology, Vol. 24 (2), (1983).

Qaththân, al-, Mannâ', al-Tasyrí wa al-Fiqh fí al-Islâm: Târîkhan wa Manhajan, Bayrût: Muassasah alRisâlah, 1982.

Rao, Vijayendra, "Dowry Inflation' in Rural India: A Statistical Investigation," dalam Population Studies, Vol. 47 (2), (1993).

Rao, Vijayendra, dan V.N. Rao, "The Dowry System in Indian Marriages: Attitudes, Expectations and Practices," dalam International Journal of Sociology of the Family, Vol. 10 (Jan-June), (1980).

Reimer. E, "Women, Dowries, and Capital Investment in Thirteenth-century Siena," dalam The Marriage Bargain: Women and Dowries in European History, M. Kaplan, ed, New York: Havorth Press, 1985.

Ribka, P. Diana, Tindak Kekerasan terhadap Perempuan dalam Keluarga, Tesis Master, Jakarta: Program Studi Kajian Wanita, Pascasarjana Universitas Indonesia, 1988.

Roa, Vijayendra, "The Rising Price of Husbands: a Hedonic Analysis of Dowry Increases in Rural India," dalam Journal of Political Economy, Vol. 101, (1993).

Rodrigues, Ana M.S.A., "For the Honor of Her Lineage and Body: The Dowers and Dowries of Some Late Medieval Queens of Portugal," dalam e-JPH, Vol. 5, (1), (Summer, 2007).

Rudd, Jane, "Dowry-Murder: An Example of Violence against Women," dalam Women's Studies International Forum, Vol. 24, (5), (2001).

Saller, Richard P. "Roman Dowry and the Devolution of Property in the Principate," dalam Classical Quarterly, Vol. 34 (1), (1984).

Samaluthi, as-, Nabil. M. Taufik, Pengaruh Agama terhadap Struktur Keluarga, diterjermah kan oleh Anshori Umar Sitanggal, Surabaya: Bina Ilmu, 1991.

Sandanshiv, D.N. dan J. Mathew. "Legal Reform in Dowry Laws," dalam Kalis Yug: Empowerment, Law and Dowry Death, R.Jethmalani, ed, New Delhi:
HarAnand, 1995.

Saroja, K. dan S.M. Chandrika "Income and Dowry: Some Revealing Connections," dalam Indian Journal of Social Work, Vol. 52 (April), (1991).

Siddiqui, Mona, "Mahr: Legal Obligation or Rightful Deman?," dalam Journal of Islamic Studies, Vol. 6 (1), (1995).

Singh, Rakesh K., "Law of Dower (Mahr) in India," dalam Journal of Islamic Law and Culture, Vol. 12, (1), (2010).

Sirohi, Seema, Sita's Curse, Stories of Dowry Victims, New Delhi: HarperCollin Publishers India, 2003.

Sitaraman, Bhavani, "Law as Ideology:Women, Courts and 'Dowry Deaths' in India," dalam International Journal of the Sociology of Law, Vol. 27, (1999).

Stark, Rodney, Sociology, Belmont, California: Wadsworth Publishing Company, 1989.

Stone, Linda dan Caroline James "Dowry, Bride Burning and Female Power in India," dalam Gender in CrossCultural Perspectives, Caroline B. Brettell and Carolyn F. Sargent, eds., New Jersey: Prentice Hall, 1997.

Stuard, Susan M., "Dowry Increase and Increments in Wealth in Medieval Ragusa (Dubrovnik)," Journal of Economic History, Vol. 41 (4), (1981).

Sujatmiko, Iwan Gardono, "Stratifikasi Sosial dan Mobilitas Sosial," dalam Jurnal Sosiologi Indonesia, No. 1, (1996).

Suran, Luciana, at.al., "Does Dowry Improve Life for Brides? A Test of the Bequest Theory of Dowry in Rural Bangladesh," Policy Research Division Working Paper No. 195, (Population Research Council, Inc., 2004).

Suyûthî, al-, Jalâl al-Dîn 'Abd al-Rahmân ibn Abî Bakr, Ikhtilâf al-Madzâhib, 'Abd al-Qayyûm Muhammad Syâfi'al-Basthawí, ed. Kairo: Dâr al-I'tishâm, 1987.

Syâh Wali Allâh, Aḥmad ibn 'Abd al-Rahím al-Fârûqî al-Dahlawi, al-Inshâf $f$ Bayân Sabab al-Ikhtilâf fì al-Ahkâm al-Fiqhiyyah, Kairo: al-Mathba'ah alSalafiyah, $1385 \mathrm{H}$.

Tambiah, Stanley J, "Bridewealth and Dowry Revisited: The position of Women in Sub-Saharan Africa and North India," dalam Current Anthropology, Vol. 30 (4), (1989).

, "Dowry and Bridewealth and the Property Rights of Women," dalam Bridewealth and Dowry, Jack Goody dan Stanley J. Tambiah, eds. London: Cambridge University Press, 1973.

Theodorson, George dan Lucille Theodorson, Sociology:Principles and Applications, St. Paul, MN, USA: West Publishing Company, 1990. 
Upadhya, C.B., "Dowry and Women's Property in Coastal Andhra Pradesh," dalam Contributions to Indian Sociology, Vol. 24 (1), (1990).

Wani, M.A. The Islamic Institution of Mahr: A Study of Its Philosophy, Working and Related Legislations in the Contemporary World, Kashmir, Upright Study Home, 1996.
Wright, Burton, et.als, Perspective:An Introduction to Sociology, Hinsdale, Illinois: The Dryden Press, 1975.

Zahrah, Muhammad Abu, Membangun Masyarakat Islami, diterjemahkan oleh Shodiq Noor Rahmat. Jakarta: Pustaka Firdaus, 1994. 